COASTAL FLOOD OF FEBRUARY 7, 1978

IN MAINE, MASSACHUSETTS,

\title{
AND NEW HAMPSHIRE
}

\section{U. S. GEOLOGICAL SURVEY}

WATER - RESOURCES INVESTIGATIONS 79-61

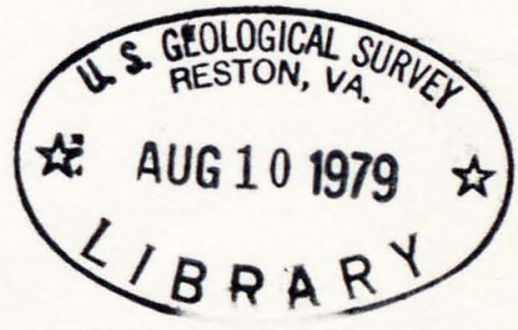

PREPARED IN COOPERATION WITH THE

U.S. ARMY CORPS OF ENGINEERS AND THE

MASSACHUSETTS DEPARTMENT OF PUBLIC WORKS

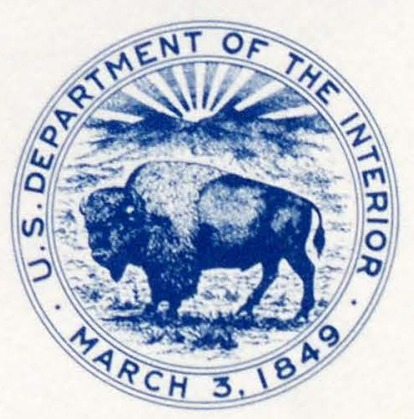



COASTAL FLOOD OF FEBRUARY 7, 1978, IN

MAINE, MASSACHUSETTS, AND NEW HAMPSHIRE

By Russell A. Gadoury

U.S. GEOLOGICAL SURVEY

Water-Resources Investigations 79-61

Prepared in cooperation with the

U.S. ARMY CORPS OF ENGINEERS and the

MASSACHUSETTS DEPARTMENT OF PUBLIC WORKS

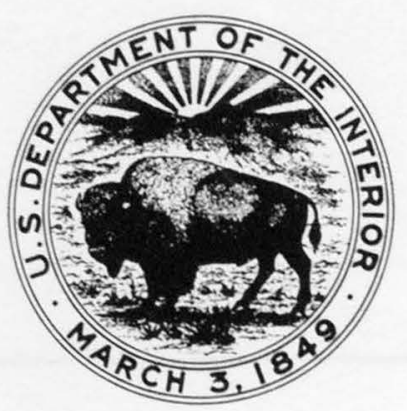


UNITED STATES DEPARTMENT OF THE INTERIOR

CECIL D. ANDRUS, Secretary

GEOLOGICAL SURVEY

H. William Menard, Director

Open-File Report

For additional information write to:

U.S. Geological Survey

150 Causeway Street, Suite 1001

Boston, MA 02114 


\section{METRIC EQUIVALENTS}

The following factors may be used to convert the inch-pound units used in this report to the International System of Units (SI):

Multiply inch-pound units

$$
\text { inch (in) }
$$

foot $(\mathrm{ft})$

mile (mi)
By

25.4

0.3048

1.609
To obtain SI Units

millimeter $(\mathrm{mm})$

meter $(\mathrm{m})$

kilometer $(\mathrm{km})$ 

Metric equivalents

Abstract-

Introduction-

Purpose and scope-

Acknowledgments--

The storm and its effects

Coastal flooding

Flood elevations

Historical flood data

Selected references

\section{ILLUSTRATIONS}

(Plates are in pocket.)

Plate I. Map of Maine coast showing locations of high-water marks.

2. Map of Massachusetts and New Hampshire coast showing

locations of high-water marks.

Figures 1-8. Photographs showing:

I. Destroyed houses along Scituate-Marshfield shoreline--------- 4

2. North Scituate Beach seawall destroyed by waves -.........-. 5

3. Surf pounding and overflowing seawall in Revere -......-. 6

4. Flooded streets behind seawall in Revere-.............- 7

5. Floodwaters raising Musquashcut Pond level in Scituate ------- 8

6. Dune erosion in Brewster on Cape Cod--..--..- 9

7. Floodwater high-water marks on Revere home -...-...--- 10

8. Wave and stillwater levels in Marblehead-_..............- 12

\section{TABLES}

Table I. Flood data in Maine, New Hampshire, and Massachusetts --.--_------ 14

2. Historical flood data in Maine and Massachusetts:

Part A. Maine

Part B.

Massachusetts

Part C.

Portland, Maine, tide records

56

Part D. Boston, Massachusetts, tide records - 


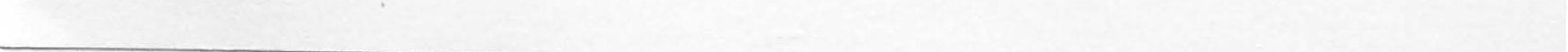




\section{COASTAL FLOOD OF FEBRUARY 7, 1978, IN \\ MAINE, MASSACHUSETTS, AND NEW HAMPSHIRE}

By Russell A. Gadoury

\section{ABSTRACT}

On February 6-8, 1978, New England was battered by one of the most severe winter storms of record. The storm produced record snowfall in many areas of Rhode Island and Massachusetts. Spring high tides (sun and moon in such alinement as to cause the highest tides of the month), a stationary storm center, and hurricane force winds combined to produce record high flood levels along much of the Massachusetts to Maine coastline on February 7. Tidal gages recorded new highs of $10.4 \mathrm{feet}$ in Boston, Massachusetts, and 9.6 feet in Portland, Maine. Fifty-four lives were lost because of the storm. Property damage was greatest along the Massachusetts coastline north of Cape Cod. The total cost of the storm--principally property damage, snow removal, and economic losses--approached \$I billion.

This report contains data which document the flooding along parts of the New England coast. Elevations of 203 floodmarks in Massachusetts, 104 in Maine, and 46 in New Hampshire are given. Also included are some historical coastal flood data and a list of other storm-related studies.

\section{INTRODUCTION}

\section{Purpose and Scope}

One of the major responsibilities of the U.S. Geological Survey is to evaluate the Nation's water resources. The Survey collects, compiles, and analyzes water data and documents extreme hydrologic events such as droughts and floods. The Survey has documented many riverine floods, but has collected only scant data on coastal or estuarine flooding. This report contains data which document the coastal flooding caused by the storm commonly referred to as "The Blizzard of 1978."

Many local, State, and Federal agencies are responsible for, or concerned with, one or more aspects of flood-plain management, including flood insurance and flood-plain zoning. The data contained in this report will provide useful information for coastal flood-plain management from Cape Cod to the Canadian border.

This report contains elevations of 203 high-water marks in Massachusetts, 104 in Maine, and 46 in New Hampshire. The high-water marks were found along the immediate coast, in sheltered bays, and in estuaries of selected rivers. 
The setting of high-water marks and the preparation of this report were made possible through funding by the U.S. Army Corps of Engineers. Surveys of high-water marks were made by the Massachusetts Department of Public Works and the New England Division of Corps of Engineers. Photographs of flooding and damage were provided by The Boston Globe and Boston Herald American.

\section{THE STORM AND ITS EFFECTS}

The storm, called "The Blizzard of 1978," formed in the Carolinas and moved northward along the Atlantic seaboard. By Monday morning, February 6, its center hod reached a position between Long Island and Cape Cod. It remained in that position almost 48 hours before finally moving slowly out to sea on Wednesday.

Winds accompanying the storm were of hurricane force. Peak wind velocities of $79 \mathrm{mi} / \mathrm{h}$ at Logan Airport in Boston and $92 \mathrm{mi} / \mathrm{h}$ at Chatham Weather Station on Cape Cod were recorded, and winds in excess of $100 \mathrm{mi} / \mathrm{h}$ were unofficially reported elsewhere in Massachusetts. Most of the New England coastline from Provincetown, Cape Cod, to eastern Maine received the full effects of northeasterly winds. That coastline wos flooded during the evening of February 6 and midmorning of February 7. On February7, tidal gages recorded new highs of $10.4 \mathrm{feet}$ in Boston and 9.6 feet in Portland. The predicted highs at these gages were $6.6 \mathrm{feet}$ and $6.4 \mathrm{feet}$, respectively. The tide level of 10.1 feet recorded in Boston during the evening of February 6 equaled the previous record set in 1851. In Portland, the previous high of 8.7 feet occurred in 1944 and 1945.

The storm produced record snowfall in many areas. Parts of Rhode Island and Massachusetts received more than 30 inches of snow, and most of southern New England received more than 20 inches. Vehicles were banned from highways in most of Massachusetts and Rhode Island for as long as a week, while local and State agencies cleared snow-clogged streets.

The storm took 54 lives. Ten thousand people were evacuated from coastal areos. Flooding resulted in more than 2,000 coastal homes being destroyed, 10,000 damaged, and almost 30,000 affected to some extent, and caused about $\$ 400$ million of damage. Property damage was greatest in Massachusetts, principally between Marblehead and Plymouth. The total cost of the storm--property damage, snow removal operations, and economic losses--approached $\$$ I billion (Platt and McMullen, 1978.)

\section{COASTAL FLOODING}

Coastal flooding, and the damage that may result, depends on three factors: tide, storm surge, and wave action. Under normal weather conditions, flooding is a function of the daily and monthly variations in tide levels. Tide levels are dependent upon the relative positions of sun and moon. The highest tide of the month is called a spring tide.

Unusual weather conditions will cause tides to vary from the normal levels. With offshore winds or high barometric pressure, tide levels will be lower than normal; with onshore winds or low barometric pressure they will be higher. Onshore winds and low barometric pressure produce a surge that adds height to the normal tide level. 
The extent and magnitude of coastal flooding resulting from a storm depends upon the severity, timing, and duration of the storm. If the storm passes quickly at a time of low tide, flood damage will be minimal. If it occurs at a time of high tide, flood damage will be more extensive. If the storm stalls and persists for more than one tide cycle, ocean water from the initial storm surge will not fully recede, and additional surges from the second and succeeding tides will increase flood levels.

Waves caused by high winds can be more of a factor in flooding and damage than the combination of surge and tide. Flooding from wave action can take many forms. The storm surge may not reach the height of a seawall, but waves may overtop it. Water passing over (overwash) a barrier can damage structures behind it. Waves crashing over a seawall can even destroy buildings from a vertical direction. Observers witnessed one home being demolished by three successive waves that fell onto the roof. Figures $1-5$ illustrate direct and indirect flooding and consequent damage.

Damage in areas not protected by seawalls, dikes, or dunes can be caused by plunging waves and wave bores at normally unaffected elevations. Once a wave has broken, the onshore rush of water, called a bore, will continue up the beach. Waves may overwash natural protective barriers. Erosion of the barriers may destroy, or render unsafe, structures thereon (fig. 6).

The extent of flooding is also a function of exposure to the elements. Just a few degrees variation in wind direction may determine if a particular point on the coastline will sustain great, moderate, or slight damage. Flood levels on two sides of a roadway, or lee and windward sides of an island, may be substantially different. The size of bridge and culvert openings will determine the amount of flooding in inlets and river estuaries.

The "Blizzard of 1978" raised havoc with the coastline because the storm occurred at the worst possible time. It stalled in the critical position for two tide cycles, came of the time of spring tides, and had high onshore winds. The storm surge produced tides 4 to 6 feet above predicted levels and, in places, was accompanied by waves as high as 10 feet.

\section{FLOOD ELEVATIONS}

The highest levels that floodwaters reach can often be detected from evidence such as a line of debris, trash, salt, oil, or snow (fig. 7). Determination of the elevation of these marks can readily be made by spirit-leveling from points of known elevation. Most floodmarks given herein were identified by personnel of the U.S. Geological Survey during the week after the flood. Additional marks in selected estuaries were identified the following week.

Floodmarks represent the variety of flooding conditions discussed in the previous section--tidal surge, wave bore, or overwash. Marks were sought that would represent stillwater conditions, unaffected by splash from winds and waves. Where possible, marks chosen were based on the physical evidence and verified by observations of witnesses.

Table I contains elevations and descriptions of 353 high-water marks in Maine, New Hampshire, and Massachusetts. The first column shows the site numbers. The locations of all high-water marks are plotted in plates I and 2.

The second column of table I gives the elevation, expressed in feet above National Ceodetic Vertical Datum of 1929, of each floodmark, as determined by third-order leveling from bench marks or as furnished by the agency noted in the description. Most elevations are shown to hundredths of a foot. Note that the elevations were surveyed to that degree of refinement, but that actual flood levels may have been somewhat different, as explained later under "accuracy rating of floodmarks." 


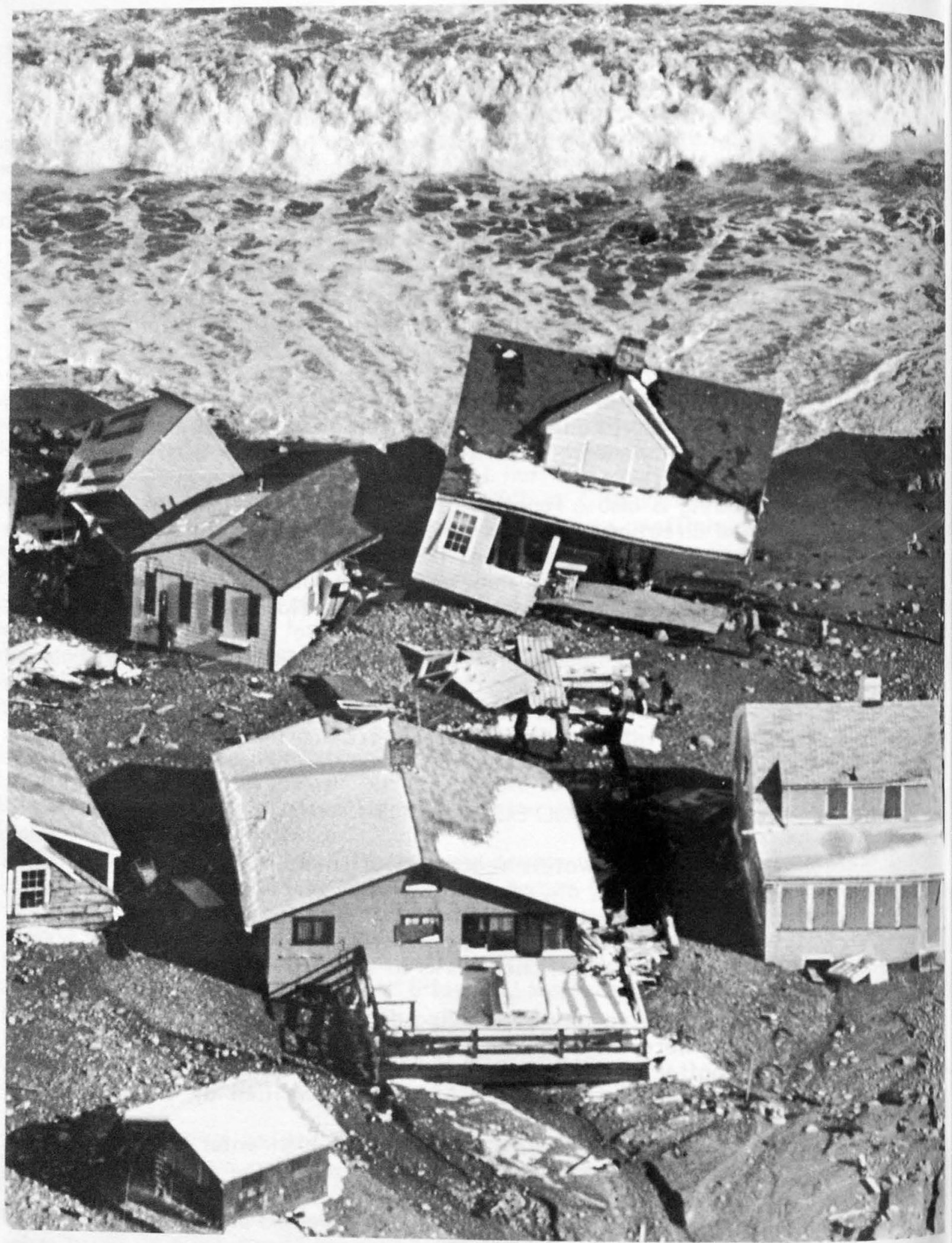

Figure 1.--Waves reduced these houses along the Scituate-Marshfield, Mass., shoreline to tangled wreckage (photograph by Kevin Cole, Boston Herald American) 




Figure 2.--Portions of the North Scituate Beach seawall in Massachusetts were destroyed by pounding surf (photograph courtesy of The Boston Globe) 


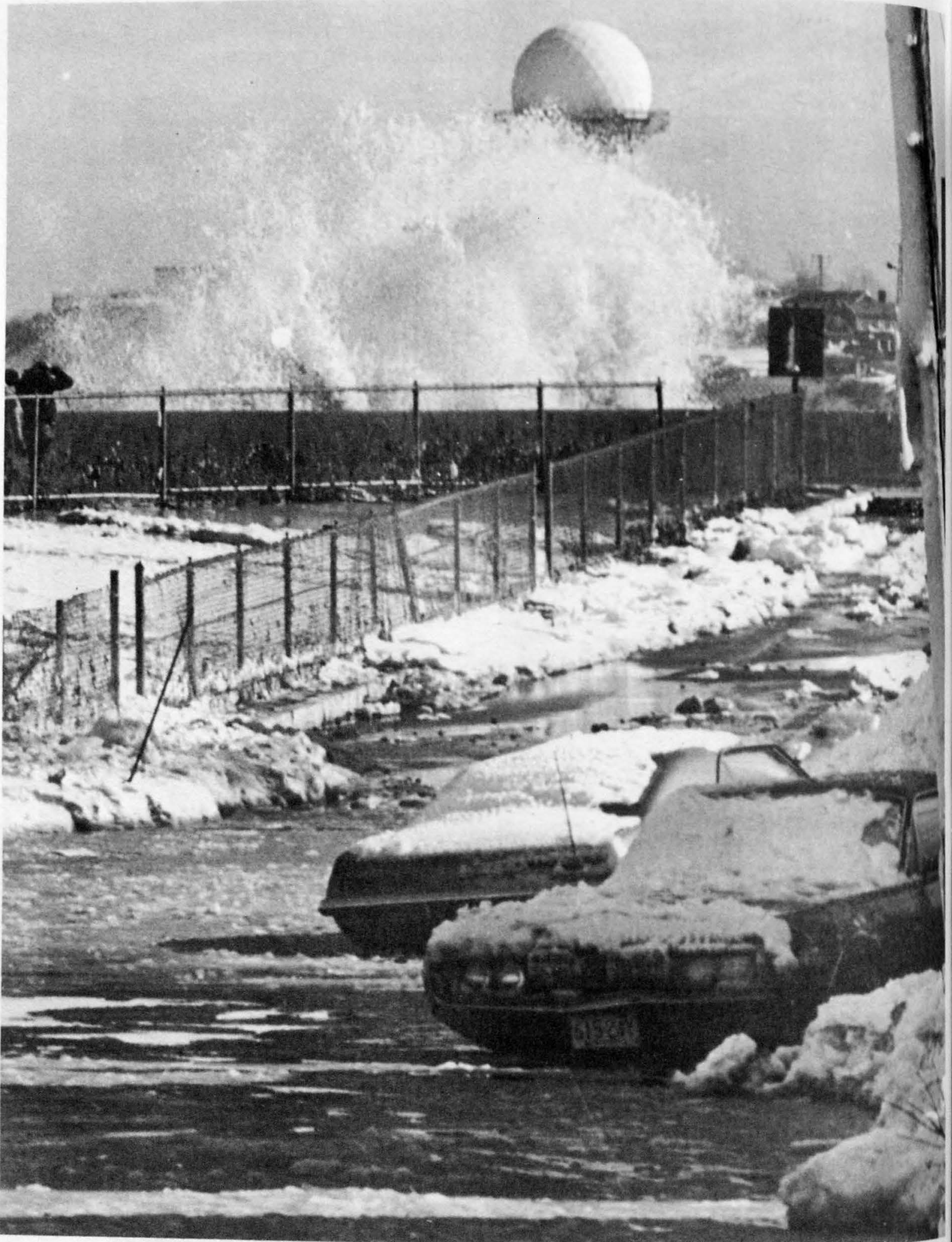

Figure 3.-- Water from waves overtopping the seawall runs down Leverett Avenue in Revere, Mass. (photograph courtesy of The Boston Globe) 


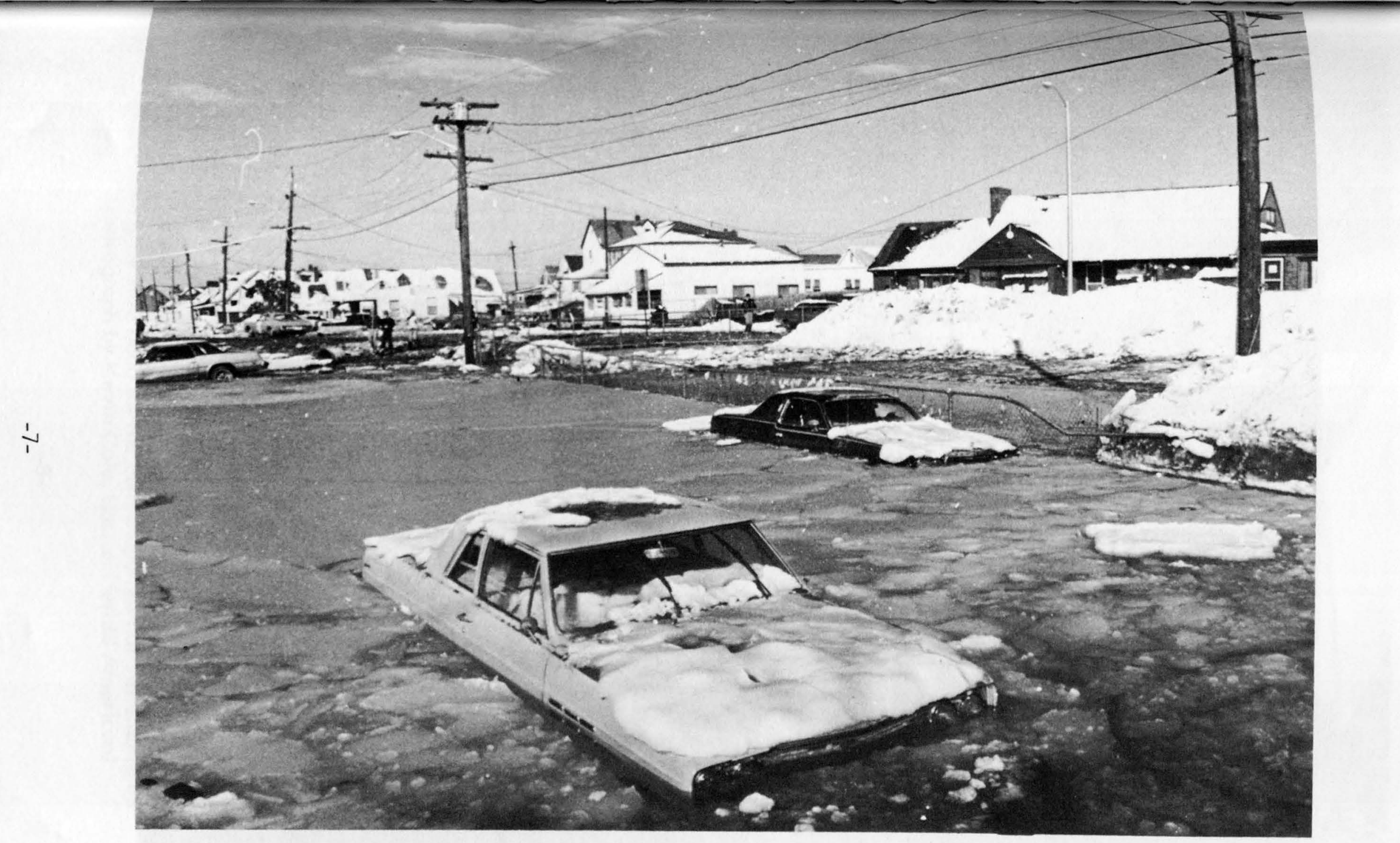

Figure 4.--Winthrop Drive, in the Beachmont section of Revere, Mass., was flooded by waves and tidal surge that overflowed the seawall (photograph courtesy of The Boston Globe) 


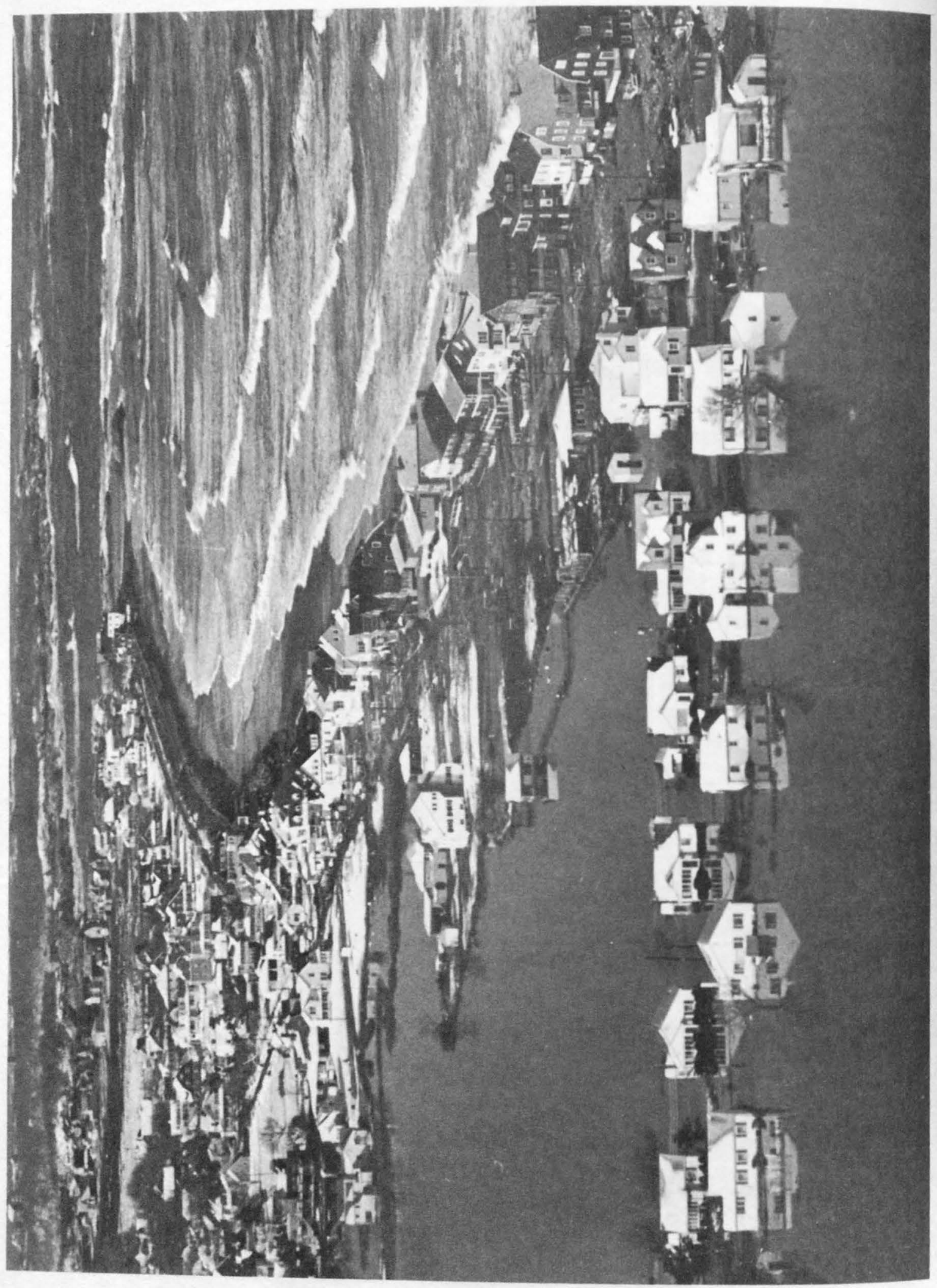




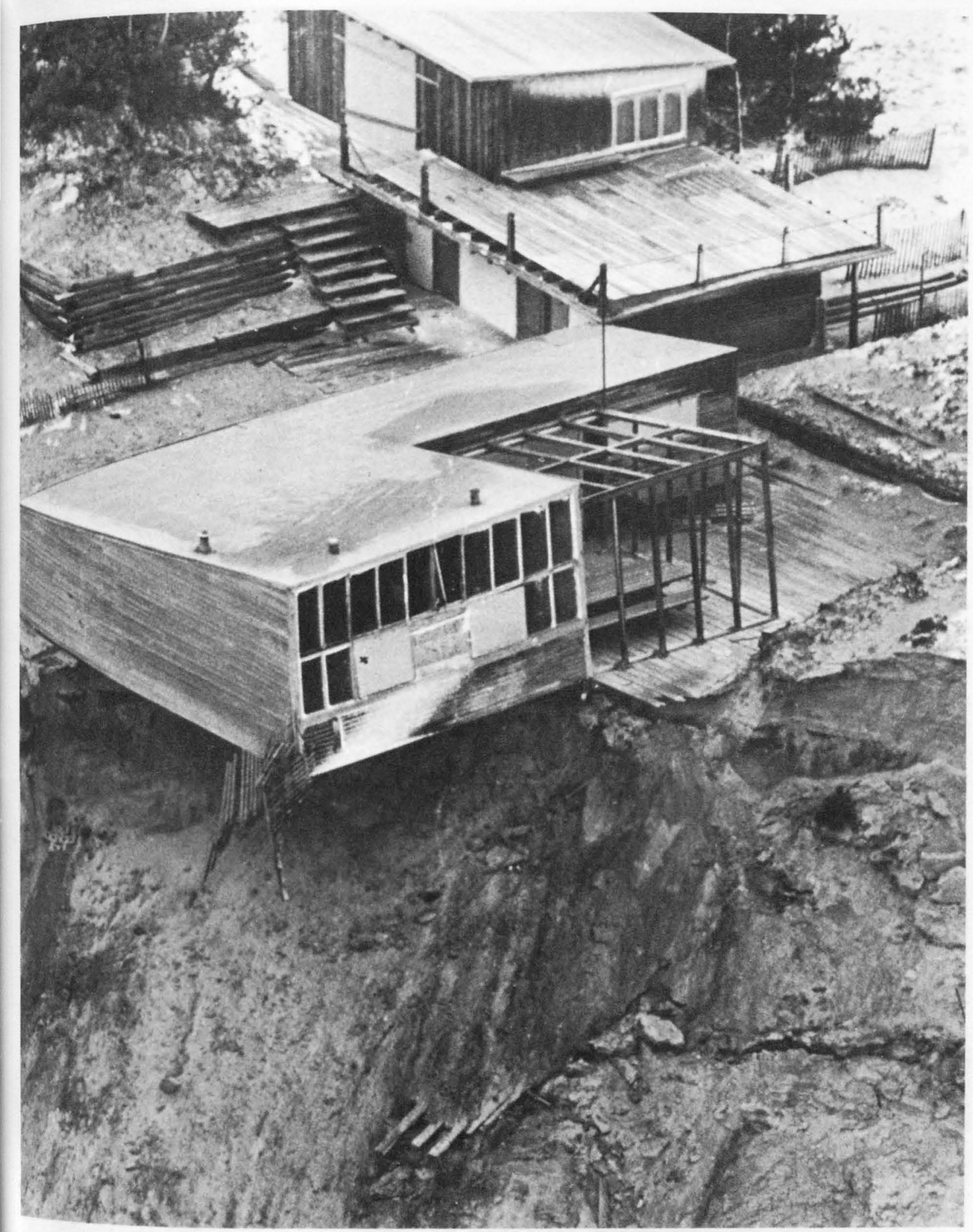

Figure 6.--Dunes on Cape Cod in Brewster, Mass., were eroded by the storm. The foreground structure suffered severe damage. The home in the background is not necessarily safe because the dune slope has not yet stabilized (photograph by Kevin Cole, Boston Herald American) 


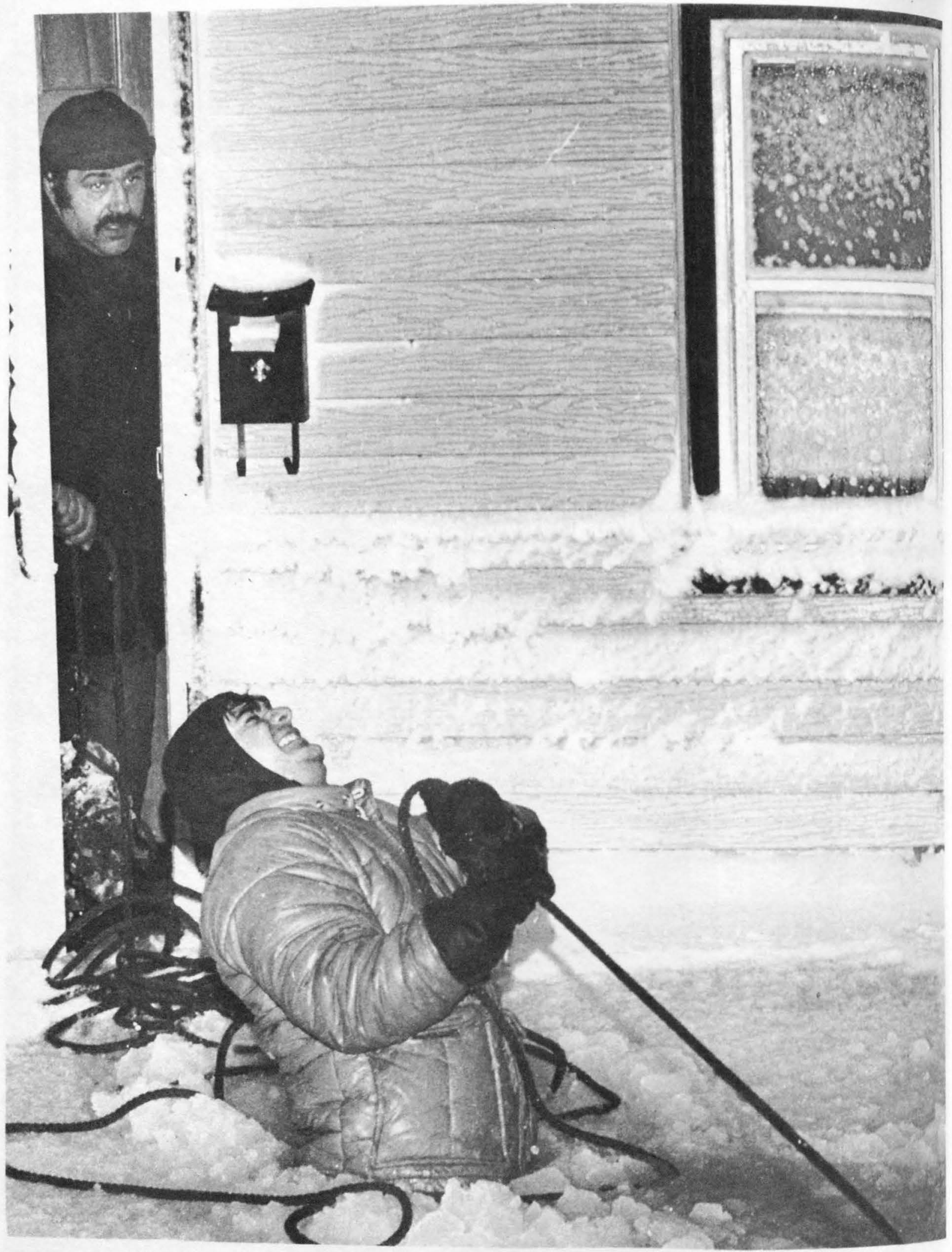

Figure 7.--Rescue worker struggles to haul evacuation boat to the front door of this home in Revere, Mass. Note the excellent high-water mark just above the window sill level (photograph by Paul Benoit, Boston Herald American) 
The third column of table I describes each floodmark and factors affecting it: location, type of floodmark and its relative accuracy, how identified, whether or not the mark was photographed, and a judgment of the cause of flooding (tidal surge, wave bore, overwash, or entrapment).

Each floodmark is located by latitude, longitude, nearest town, and a precise description of the immediate area.

The accuracy and type of mark is described as "good seed line," "fair debris," "excellent wetline in building transferred to ...," and the like. The last example in the foregoing describes an interior floodmark transferred to a permanent exterior object, such as a telephone pole, for ease of subsequent surveying. Figure 8 illustrates the advantages of retrieving floodmarks from inside buildings where wave effects are virtually eliminated. Accuracy ratings of "excellent," "good," "fair," or "poor" are terms used to indicate the degree of reliability of the flood evidence. "Excellent" means a smooth horizontal line of material was found. "Good" indicates there was some variation in the level of the flood evidence, with the average height being marked. "Fair" or "poor" marks mean flood evidence was more scattered but that the point selected seemed to be a reasonable average of marks in the immediate area.

Following the phrase showing the accuracy and type of mark, is a statement of how the mark was permanently identified. Nails, high-water-mark disks, red plastic tape (called flagging), spray paint, and surveyor's crayon (keel) were used for identification. If the reference point was not set at the actual floodmark elevation, the elevation of the reference point is given, for example, "(elev $14.32 \mathrm{ft}) . "$

Judgments given for "the cause of flooding should be accepted with caution, particularly with regard to "tidal surge." In the strictest sense, tidal surge is that extra tide height caused by barometric pressure differential and general wind direction of a storm, and does not include added heights caused by wave action. Tidal gages are carefully designed to record tidal surge. Most floodmark sites were in more exposed areas, with greater chance of some wave effect. If wave action, wave bores, or overwash were estimated to have had an insignificant effect, the flood elevation was presumed to represent surge. No distinction was attempted between "open-coast" surge and "estuar ine" surge.

\section{HISTORICAL FLOOD DATA}

A storm on February 2, 1976, caused a tidal bore that resulted in flooding at Bangor, Maine, and the adjacent coastline. This flood was documented at several sites (Morrill, 1977). Several of these sites were visited after the February 7, 1978, flood, and marks from this later storm were recovered where possible. During this visit, it was found that a storm on January 9, 1978, also caused flooding that, in places, was higher than that on February 7.

A record of previous floodmarks was found at the Old lce House near Hugo's Lighthouse Restaurant in Cohasset, Massachusetts. Several flood elevations as early as 1851 are recorded on a board attached to the Old Ice House. It is not known if all intervening floods were recorded, but the flood elevation of February 7, 1978, is the highest recorded.

Records are available for several tide gages operated by the National Ocean Survey. The highest tide levels for gages in Boston and Portland have been obtained.

Elevations of the above-mentioned historical flood data are given in table 2 . Because the sea level has been gradually rising, a column headed "Adjusted Elevation" has been added to parts B, C, and D. Elevations shown are the elevations earlier storms would have reached if they had occurred in the year indicated (Hicks, 1978). 


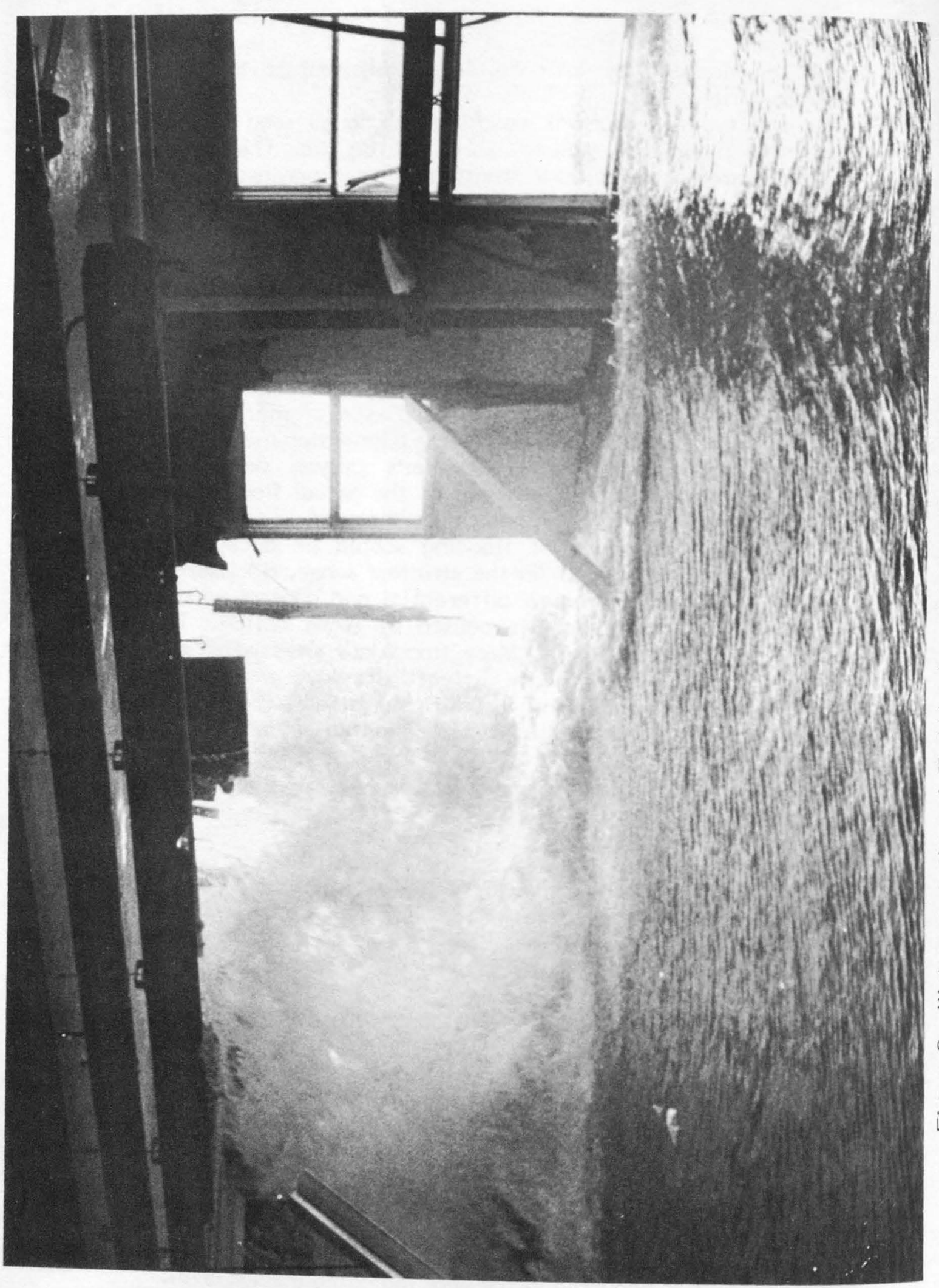




\section{SELECTED REFERENCES}

It is beyond the scope of this report to include the data or conclusions of the many studies and reports on various aspects of "The Blizzard of 1978," but following is a bibliography of the reports on file in the Boston office of the U.S. Geological Survey.

Boston Herald American, February 9, 1978, Storm souvenir edition (pictorial account of the worst storm ever to hit Massachusetts): Boston, Mass., Boston Herald American, $16 \mathrm{p}$.

Boston State College, 1978, The blizzard of 1978, it's effects on the coastal environments of southeastern New England: Boston, Mass., Proceedings of conference of May 12, 1978, 115 p.

Corps of Engineers, New England Division, 1979, Blizzard of '78, coastal storm damage study: Waltham, Mass., $161 \mathrm{p}$.

Hicks, S. D., 1978, An average geopotential sea level series for the United States: Journal of Geophysical Research, v. 83, no. C3., p. 1378.

McCartney, David, 1978, Historical significance of tidal flooding on Connecticut coast, February 6, 1978: U.S. Geological Survey memorandum from District Chief, Connecticut, to Regional Hydrologist, Reston, Va., February 16, 1978, 8 p.

Morrill, R. A., 1977, Maine coastal flood of February 2, 1976: U.S. Geological Survey Open-File Report 77-533, 30 p.

New England River Basins Commission, 1978, Summary of workshop on the 1978 coastal flood disaster in New England, held on March 30, 1978: Boston, Mass., 13 p.

Platt, R. H., and McMullen, George, 1978, Coastal flooding in Massachusetts, February 67, 1978: Some preliminary data: Amherst, Mass., University of Massachusetts, 9 p.

The Boston Globe, 1978, Special section on Blizzard '78 (details in words and pictures, how and why the storm happened, and to whom): Boston, Mass., The Boston Sunday Globe, February 19, 1978, 24 p. 
Table I.--Flood data in Maine, New Hampshire, and Massachusetts

(Elevations, in feet above NGVD of 1929, and descriptions of documented USGS high-water marks for the storm of February 7, 1978.

Site numbers are the same as those shown on plates I and 2.)

\begin{tabular}{|c|c|c|}
\hline $\begin{array}{l}\text { Site } \\
\text { No. }\end{array}$ & $\begin{array}{c}\text { Elevation } \\
(\mathrm{ft})\end{array}$ & Description \\
\hline 1 & 12.34 & 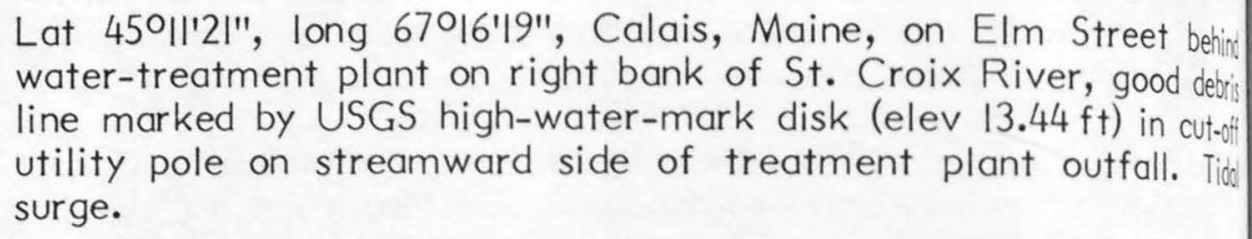 \\
\hline 2 & 10.67 & $\begin{array}{l}\text { Lat } 44^{\circ} 58^{\prime} 28^{\prime \prime} \text {, long } 67^{\circ} 04^{\prime} 30^{\prime \prime} \text {, Perry, Maine, good ice ring marked by } \\
\text { a USGS high-water-mark disk (elev } 12.06 \mathrm{ft} \text { ) in cut-off utility pole } \\
\text { old bridge site on left bank of Little River } 200 \mathrm{ft} \text { upstream from ner } \\
\text { bridge on U.S. Route I. Tidal surge. }\end{array}$ \\
\hline 3 & 12.66 & $\begin{array}{l}\text { Lat } 4405 I^{\prime} 33^{\prime \prime} \text { long } 66^{\circ} 58 ' 59 " \text {, Lubec, Maine, excellent debris line } \\
\text { marked by a USGS high-water-mark disk (elev } 13.96 \mathrm{ft} \text { ) in A.W. Pikets } \\
\text { boathouse behind U.S. Custom House on left side of Campobello } \\
\text { Island bridge, in right, water side of doors about } 2 \text { in above floor } \\
\text { sill. Tidal surge. }\end{array}$ \\
\hline 4 & 10.42 & $\begin{array}{l}\text { Lat } 44^{\circ} 4^{\prime} / 2^{\prime \prime} \text {, long } 67023^{\prime} 28^{\prime \prime} \text {, East Machias, Maine, excellent debris } \\
\text { line marked by a USGS high-water-mark disk (elev } 12.10 \mathrm{ft} \text { ) in parking } \\
\text { lot } 13 \mathrm{ft} \text { from southwest corner of Post Office. Tidal surge. }\end{array}$ \\
\hline 5 & 11.51 & $\begin{array}{l}\text { Lat } 44^{\circ} 43^{\prime} 04^{\prime \prime} \text {, long } 67027^{\prime} I 2^{\prime \prime} \text {, Machias, Maine, marker on front } \\
\text { Sears store on U.S. Route I. Excellent wet line in store transferres } \\
\text { to a USGS high-water-mark disk (elev } 12.91 \mathrm{ft} \text { ) located on right side } \\
\text { of garage door about } 1.5 \mathrm{ft} \text { from door sill. Tidal surge. }\end{array}$ \\
\hline 6 & 12.00 & $\begin{array}{l}\text { Lat } 44^{\circ} 3 I^{\prime} 40^{\prime \prime} \text {, long } 67036^{\prime} 57 " \text {, Jonesport, Maine, good debris line } \\
\text { marked by a USGS high-water-mark disk (elev } 11.59 \mathrm{ft} \text { ) in base of } \\
\text { easternmost light pole of parking lot at public boat landing, about } \\
0.1 \text { mi off State Route } 187 \text {. Tidal surge. }\end{array}$ \\
\hline 7 & 10.37 & $\begin{array}{l}\text { Lat 44030'28", long 67043'22", Addison, Maine, South Addison, } \\
\text { excellent wet line in building transferred to a USG5 } \\
\text { high-water-mark disk (elev } 10.87 \mathrm{ft} \text { ) on southeast corner of building } \\
\text { on D. W. Look \& Son wharf about } 3 \mathrm{ft} \text { above wharf on Eastert } \\
\text { Harbor. (South Addison is also called Eastern Harbor.) Tidul surge. }\end{array}$ \\
\hline 8 & 10.06 & $\begin{array}{l}\text { Lat } 44^{\circ} 37^{\prime} 04^{\prime \prime} \text {, long } 67044^{\prime} 43^{\prime \prime} \text {, Addison, Maine, excellent wet line in } \\
\text { building transferred to a USGS high-water-mark disk (elev } 10.44^{\prime \prime \prime} \\
\text { in southwest corner of Smith's Clam Shop on left bank of West } \\
\text { Branch of Pleasant River just below bridge. Tidal surge. }\end{array}$ \\
\hline
\end{tabular}




\begin{tabular}{|c|c|c|}
\hline $\begin{array}{l}\text { Site } \\
\text { No. }\end{array}$ & $\begin{array}{c}\text { Elevation } \\
(\mathrm{ft})\end{array}$ & Description \\
\hline 9 & 9.97 & $\begin{array}{l}\text { Lat } 44^{\circ} 37^{\prime} 10^{\prime \prime} \text {, long } 670485^{\prime \prime} \text {, Harrington, Maine, good ice line } \\
\text { marked by a USGS high-water-mark disk (elev } 11.39 \mathrm{ft} \text { ) in northwest } \\
\text { side of office building on right side of door casing on rear door, } \\
\text { about } 3 \text { in above sill. Building is located on Water Street between } \\
\text { street and small stream about } 100 \mathrm{ft} \text { below second culvert on right } \\
\text { bank. Tidal surge. }\end{array}$ \\
\hline
\end{tabular}

9.70 Lat 44035'48', long 67055'34', Cherryfield, Maine, excellent ice and debris line marked by a USGS high-water-mark disk (elev 10.48ft) in base of triple elm on right bank of Narraguagus River about $150 \mathrm{ft}$ downstream from U.S. Routel bridge and across road from Tracy's Motel on left bank of small brook. Tidal surge.

10.10 Lat 4403I'53", long 67052'58", Milbridge, Maine, junction of U.S. Route I and Wyman Road, excellent wet line in barn transferred to a USGS high-water-mark disk (elev 9.91 ft) in southeast corner of storage barn (attachment to main barn) across road from Wyman Canning Co. office. Tidal surge.

9.91 Lat 44023'36", long 68005'08", Winter Harbor, Maine, 0.1 mi west of State Route 186 in Henry Cove, good debris line marked by a USGS high-water-mark disk (elev $9.57 \mathrm{ft}$ ) in northwest corner of 20- by 20 -ft shed across road from town garage, just west and across road from gas station. Tidal surge.

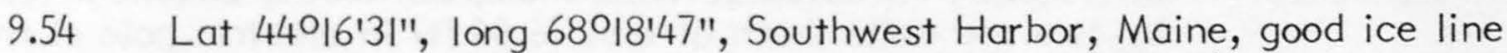
marked by a USGS high-water-mark disk (elev $8.23 \mathrm{ft}$ ) in top timber curb of U.S. Coast Guard pier. Marker is just right of the most right-hand parking space for U.S. Coast Guard Cutter Brindle, just below concrete deck of pier. Tidal surge.

II.53 Lat 44032'25", long 68025'34", Ellsworth, Maine, on Water Street on left bank of Union River, about 0.1 mi downstream from U.S. Routel, excellent debris and wash line marked by a USGS high-water-mark disk (elev $10.90 \mathrm{ft}$ ) in base of elm tree behind body shop of Morrison Chevrolet. Tidal surge.

11.42 Lat 44024'47", long 68035'14", Blue Hill, Maine, on left downstream side of Mill Stream, about $100 \mathrm{ft}$ below culvert on State Route 176, excellent wet line in building transferred to a nail (elev $9.42 \mathrm{ft}$ ) driven in side of shop building of Babson and Duffy Plumbing and Heating, located $2 \mathrm{ft}$ from left side of door as you enter building; oil slick on third clapboard from bottom of building. Tidal surge. 
Table I.--Flood data in Maine, New Hampshire, and Massachusetts (Continued)

\begin{tabular}{|c|c|c|}
\hline $\begin{array}{l}\text { Site } \\
\text { No. }\end{array}$ & $\begin{array}{c}\text { Elevation } \\
(\mathrm{ft})\end{array}$ & Description \\
\hline 16 & 9.12 & $\begin{array}{l}\text { Lat } 44^{\circ} 18^{\prime} 14^{\prime \prime} \text {, long } 68^{\circ} 36^{\prime} 45^{\prime \prime} \text {, Sedgwick, Maine, excellent debris line } \\
\text { marked by a nail (elev } 9.51 \mathrm{ft} \text { ) in base of utility pole } 47 \text { on right } \\
\text { downstream side of causeway at Benjamin River. Tidal surge. }\end{array}$ \\
\hline 17 & 9.54 & $\begin{array}{l}\text { Lat } 44^{\circ} 177^{\prime} 48^{\prime \prime} \text {, long } 68^{\circ} 4 I^{\prime \prime} 15 " \text {, Sedgwick, Maine, excellent ice and } \\
\text { debris marked by a USGS high-water-mark disk (elev } 9.52 \mathrm{ft} \text { ) } 2.75 \mathrm{ft} \\
\text { below top of concrete footing on northeast corner of Deer Isle } \\
\text { bridge over Eggemoggin Reach. Tidal surge. }\end{array}$ \\
\hline 18 & 9.24 & $\begin{array}{l}\text { Lat 44023'52", long } 68^{\circ} 42^{\prime} 19^{\prime \prime} \text {, Brooksville, Maine, } 0.3 \mathrm{mi} \text { east of } \\
\text { North Brooksville, excellent debris marked by a USGS } \\
\text { high-water-mark disk (elev } 7.85 \mathrm{ft} \text { ) in base of utility pole } 537 \text { on left } \\
\text { downstream bank of Bagaduce River. Tidal surge. }\end{array}$ \\
\hline 19 & 8.24 & $\begin{array}{l}\text { Lat } 44^{\circ} 23^{\prime} 16 " \text {, long } 68^{\circ} 47^{\prime} 48^{\prime \prime} \text {, Castine, Maine, excellent wet line } \\
\text { inside building transferred outside to red paint (elev } 9.16 \mathrm{ft} \text { ) on south } \\
\text { side of concrete base for extension of building } 20 \mathrm{ft} \text { in front of Capt. } \\
\text { John's Restaurant. Tidal surge. }\end{array}$ \\
\hline 20 & 10.16 & $\begin{array}{l}\text { Lat } 44034 ' 20 " \text {, long } 6804750 " \text {, Bucksport, Maine, excellent debris } \\
\text { marked by red nail (elev } 11.56 \mathrm{ft} \text { ) on light pole just bankward of St. } \\
\text { Regis Meteorological Station near municipal dock. Tidal surge. }\end{array}$ \\
\hline 21 & 11.16 & $\begin{array}{l}\text { Lat } 44^{\circ} 47^{\prime} / 4^{\prime \prime} \text {, long } 68^{\circ} 46^{\prime} 35^{\prime \prime} \text {, Bangor, Maine, at Barret Tar Pier neor } \\
\text { Interstate } 1-95 \text { entrance from Hampden Road, excellent ice marked } \\
\text { by two red nails (both at elev } 16.66 \mathrm{ft} \text { ) in electric pole at river edge } \\
\text { of dock, } 10 \mathrm{ft} \text { from pier. Tidal surge. }\end{array}$ \\
\hline
\end{tabular}

$22 \quad 10.62$ Lat 44041'40", long 68050'55", Winterport, Maine, $0.3 \mathrm{mi}$ south of Winterport-Hampden town-line marker, good debris marked by a red nail (elev $12.68 \mathrm{ft}$ ) in Bangor Hydro-Electric pole 1187 , $50 \mathrm{ft}$ from center line of bridge headed toward Hampden on U.S. RoutelA on right side of road, across from King's residence. Tidal surge.

239.56 Lat 44033'19", long 68051'33", Prospect, Maine, excellent ice line marked by a USGS high-water-mark disk (elev $12.46 \mathrm{ft}$ ) set about $1 \mathrm{ft}$ above ground in base of Central Maine Power Co. pole 5, on the south side of State Route 24, about $0.2 \mathrm{mi}$ from U.S. Route IA, and $200 \mathrm{ft}$ west from $12 \mathrm{ft}$ highway bridge over tidal flow in Prospect. Tidal surge.

Lat 44026'59", long 69002'08", Belfast, Maine, good ice and wash line marked by red paint (elev $8.93 \mathrm{ft}$ ) on left upstream abutment of lower highway bridge of Passagassawakeag River just upstream of railroad bridge, on Upper Bridge Road leading to State Route 137 . Mark is $2.3 \mathrm{ft}$ below bridge seat. Tidal surge. 
Table 1.--Flood data in Maine, New Hampshire, and Massachusetts (Continued)

\begin{tabular}{lll}
\hline $\begin{array}{c}\text { Site } \\
\text { No. } \begin{array}{c}\text { Elevation } \\
(\mathrm{ft})\end{array}\end{array}$ & Description \\
\hline 25 & 10.25 & $\begin{array}{l}\text { Lat 44025'43", long 69000'l9", Belfast, Maine, Marshall Wharf, } \\
\text { Penobscot Bay Towing Co., excellent wet line in building transferred } \\
\text { to a USGS high-water-mark disk (elev } 10.23 \mathrm{ft} \text { ) on southeast corner } \\
\text { of office building, 20 ft from wharf edge. Tidal surge. }\end{array}$
\end{tabular}

Lat 44016'58", long 69000'34", Lincolnville Beach, Maine, excellent wet line in store transferred to a USGS high-water-mark disk (elev $8.57 \mathrm{ft}$ ) set on left door frame of the main entrance to the "Beach Store," about $500 \mathrm{ft}$ south of bridge over Frohock Brook on U.S. Route I. Tidal surge.

279.02 Lat 44012'35", long 69003'5l", Camden, Maine, at Camden Harbor, excellent wash line marked by red paint (elev $8.4 \mathrm{ft}$ ) I ft up harbor from tidal gage piling near pole P5153, near tie-up of square rigger. Tidal surge.

289.75 Lat 43059'09", long 69012'l6", St. George at Long Cove, Maine, excellent debris marked by red paint (elev $8.20 \mathrm{ft}$ ) on gneiss outcrop $60 \mathrm{ft}$ from Central Maine Power Co. pole 264, on left side of State Route 131 heading toward Tenants Harbor, 0.3 mi south of Long Cove Road. Tidal surge.

299.60 Lat 44004'20", long 690/I'17", Thomaston, Maine, excellent debris marked by red paint (elev $8.68 \mathrm{ft}$ ) on downstream left abutment of Maine Central Railroad bridge over St. George River. Tidal surge.

$309.50 \quad$ Lat 44001'54", long 69022'4l", Waldoboro, Maine, at West Waldoboro, excellent debris marked by red paint (elev $8.45 \mathrm{ft}$ ) on granite outcrop, off State Route 32 toward Round Pond, first road to left, at end of road, $0.25 \mathrm{mi}$ beyond inn on dirt road, between second and third camp at set of three "Keep Out" signs. Tidal surge.

$319.26 \quad$ Lat 44001'54", long 69032'48", Newcastle, Maine, excellent ice and wash line marked by red paint mark (elev $8.15 \mathrm{ft}$ ) on granite boulder on south side of boat launch; entrance is the private road indicating Barrol's Point. Tidal surge.

329.48 Lat $44^{\circ} 00^{\prime} 07^{\prime \prime}$, long 69039'49", Wiscasset, Maine, lumber mill yard by highway bridge, excellent ice and debris marked by red paint (elev $7.68 \mathrm{ft}$ ) on concrete slab $100 \mathrm{ft}$ south of U.S. Route I. Tidal surge.

339.29 Lat 43058'25", long 69040'47", Westport, Maine, excellent ice and debris marked by red paint (elev $7.09 \mathrm{ft}$ ) on ledge $100 \mathrm{ft}$ from culvert through approach to new Westport bridge. Tidal surge. 
Table 1.--Flood data in Maine, New Hampshire, and Massachusetts (Continued)

\begin{tabular}{|c|c|c|}
\hline $\begin{array}{l}\text { Site } \\
\text { No. }\end{array}$ & $\begin{array}{c}\text { Elevation } \\
(\mathrm{ft})\end{array}$ & Description \\
\hline 34 & 9.18 & $\begin{array}{l}\text { Lat 43048'16", long 69044'52", Georgetown, Maine, excellent ice and } \\
\text { debris marked by red paint (elev } 7.27 \mathrm{ft} \text { ) on stone work of second } \\
\text { bridge from Georgetown, on far bank from Post Office, on north side } \\
\text { about } 10 \mathrm{ft} \text { from bridge and } 8 \mathrm{ft} \text { down from curbing of bridge. Tidel } \\
\text { surge. }\end{array}$ \\
\hline 35 & $\begin{array}{c}11.96 \\
\text { (disk) } \\
12.11 \\
\text { (paint) }\end{array}$ & $\begin{array}{l}\text { Lat } 43^{\circ} 49^{\prime} 24^{\prime \prime} \text {, long } 692^{\prime} 38^{\prime \prime} \text {, Geor getown, Maine, at Five Islands, } \\
\text { excellent ice and debris marked by a USGS high-water-mark disk in } \\
\text { cedar post at back side of the Post Office and general store, about } \\
3 \mathrm{ft} \text { off the ground. Also, a red paint mark } 12 \mathrm{ft} \text { east of the disk on } \\
\text { granite foundation. Tidal surge. }\end{array}$ \\
\hline
\end{tabular}

$36 \quad 8.62$ Lat 43047'0l", long 69043'27", Georgetown, Maine, at Reid State Park, excellent ice and debris marked by a USGS high-water-mark disk in a 16-in red-pine tree which has a fork about $4 \mathrm{ft}$ above the ground, $600 \mathrm{ft}$ north of dune at edge of the main beach, $400 \mathrm{ft}$ northwest of bathhouse, and $40 \mathrm{ft}$ from edge of the tidal pool, in picnic area of the park. Tidal surge.

$37 \quad 11.18 \quad$ Lat 43045'20", long 69046'35", Georgetown, Maine, near Bay Point, excellent ice and debris marked by a USGS high-water-mark disk in southwest corner of green house, $60 \mathrm{ft}$ north of fishing wharf, $5 \mathrm{ft}$ northeast of the end of concrete retaining wall, and about $2 \mathrm{ft}$ above the ledge shelf. Tidal surge.

$38 \quad 7.43 \quad$ Lat 43048'22", long 69046'43", West Georgetown, Maine, excellent debris marked by a USGS high-water-mark disk in a 20-in pine tree, $125 \mathrm{ft}$ west of a brown house, $50 \mathrm{ft}$ north of the north corner of 0 garage, $40 \mathrm{ft}$ north of a bunkhouse, and about $2 \mathrm{ft}$ above the ground. The house is 1,000 ft north of the West Georgetown Road, and the driveway to the house is $1.45 \mathrm{mi}$ west from the Bay Point Road. Tidol surge.

Lat 43050'55", long 69046'34", Arrowsic, Maine, excellent ice line in shed transferred to a USGS high-water-mark disk in northeast corner of shed in back of a red house $0.2 \mathrm{mi}$ southwest of the State Route 127 bridge over Back River. The disk is $10 \mathrm{ft}$ west of an apple tree and $1.5 \mathrm{ft}$ above the ground. The red house is near New England Telephone and Telegraph pole 3153, near a sign "Indian Rest," and $60 \mathrm{ft}$ southeast of a culvert. Tidal surge.

$40 \quad 6.95 \quad$ Lat 44002'00", long 69050'23", Bowdoinham, Maine, good ice marked by red paint on north face of the northeast abutment of State Route 24 bridge over the Abagadasset River $3.5 \mathrm{mi}$ northeast of Bowdoinham Village. Tidal surge. 
Table 1.--Flood data in Maine, New Hampshire, and Massachusetts (Continued)

\begin{tabular}{|c|c|c|}
\hline $\begin{array}{l}\text { iite } \\
\text { No. }\end{array}$ & $\begin{array}{c}\text { Elevation } \\
(\mathrm{ft})\end{array}$ & Description \\
\hline 41 & 8.89 & $\begin{array}{l}\text { Lat } 44^{\circ} 00^{\prime} 24^{\prime \prime} \text { long } 69053^{\prime \prime} 42^{\prime \prime} \text {, Bowdoinham, Maine, excellent ice } \\
\text { marked by red paint on the southeast side of bridge over Cathance } \\
\text { River in the village. The mark is on the girder I ft west of the } \\
\text { abutment and about } 3.5 \mathrm{ft} \text { below the road elevation. Tidal surge. }\end{array}$ \\
\hline 42 & 8.00 & $\begin{array}{l}\text { Lat } 43^{\circ} 54^{\prime} 52^{\prime \prime} \text {, long } 69048 ' 48 " \text {, Bath, Maine, excellent wet line in } \\
\text { building transferred to a USGS high-water-mark disk (elev } 8.09 \mathrm{ft} \text { ) on } \\
\text { the south side, near the southwest corner, and near the lower hinge } \\
\text { for the aluminum and glass entrance door of the Longreach Co. } \\
\text { building, about } 1,000 \mathrm{ft} \text { upstream of bridge over Kennebec River. The } \\
\text { elevation is approximately that of the top of the concrete base to } \\
\text { the gas pump } 20 \mathrm{ft} \text { from the door. Tidal surge. }\end{array}$ \\
\hline
\end{tabular}

Lat 43049'50", long 69048'52", Phippsburg, Maine, excellent grease line in house transferred to a USGS high-water-mark disk in the north side of the garage to the George Bowke home, opposite Stony Brook Road on State Route 209. The disk is in the door frame of the side door, near the lower hinge, and $50 \mathrm{ft}$ southeast of the house. Tidal surge.

Lat 43048'58", long 69048'36", Phippsburg, Maine, excellent ice line marked by red paint on downstream southeast wingwall of culvert for outlet of small pond, $0.5 \mathrm{mi}$ southeast along Parker Head Road from the junction of State Route 209. Tidal surge.

Lat 43047'23", long 69048'27", Phippsburg, Maine, at Parker Head, excellent debris marked by red paint on large granite outcrop $35 \mathrm{ft}$ northwest of the culvert for Parker Head Creek, $40 \mathrm{ft}$ west of the centerline of the road, and about $3 \mathrm{ft}$ above ground level. Tidal surge.

Lat 43045'l2", long 69049'33", Phippsburg, Maine, excellent ice and debris marked by a USGS high-water-mark disk in an 8-in maple tree $0.8 \mathrm{mi}$ east along State Route 209 from the junction of State Route 216, $50 \mathrm{ft}$ east of Central Maine Power Co. pole 17, and $30 \mathrm{ft}$ west of the exit of a culvert. Tidal surge.

II.32 Lat 43043'l0", long 6905I'll", Phippsburg, Maine, at Head Beach, excellent ice and sand marked by a USGS high-water-mark disk on the west face of the "Kelp Shed" building, $3 \mathrm{ft}$ from the southwest corner and about $1.5 \mathrm{ft}$ above the ground. Tidal surge.

9.19 Lat 43043'48", long 69050'20", Phippsburg, Maine, at southeast end of Cape Small Harbor, excellent ice and debris marked by a USGS high-water-mark disk in Central Maine Power Co. Pole 270 on the west edge of Small Point Road (State Route 216), 2.I mi south of the junction of State Routes 216 and $209,0.4 \mathrm{mi}$ south of a road to the east, and $20 \mathrm{ft}$ west of the centerline of the road. Tidal surge. 
Table I.--Flood data in Maine, New Hampshire, and Massachusetts (Continued)

\begin{tabular}{ccl}
\hline $\begin{array}{c}\text { Site } \\
\text { No. }\end{array}$ & $\begin{array}{c}\text { Elevation } \\
(\mathrm{ft})\end{array}$ & \multicolumn{1}{c}{ Description } \\
\hline 49 & 10.15 & $\begin{array}{l}\text { Lat } 43^{\circ} 46^{\prime 27} 27 \text {, long 69052'03", Phippsburg, Maine, near Sebasco, } \\
\text { excellent ice line in building transferred to a USGS high-water-mark } \\
\text { disk in west side of a 7- by 7-in post at southwest corner of a } \\
\text { tin-covered boat-storage building at Brewer Boat Yard, opposite the } \\
\text { north end of Harbor Island. Tidal surge. }\end{array}$
\end{tabular}

509.66 Lat 43050'16", long 6905I'00", West Bath, Maine, at Brighams Cove, excellent ice and debris marked by a USGS high-water-mark disk in the east side of the first support post west of the catwalk on south side of wooden bridge over the cove, $25 \mathrm{ft}$ west of the east end of the bridge and about $1.5 \mathrm{ft}$ above a cross timber. Tidal surge.

$51 \quad$ 10.91 Lat 43051'l0", long 69053'19", Harpswell, Maine, near Indian Point, excellent ice line marked by a USGS high-water-mark disk in the base of a twin 12-in pine tree, $200 \mathrm{ft}$ northeast of a red house with large picture windows. The driveway to the house is at the north end of the tarred road, $0.1 \mathrm{mi}$ south of the Queen of the Mission Chapel, and $1.1 \mathrm{mi}$ northeast along Indian Point Road from the intersection with Cundy's Harbor Road. Tidal surge.

$529.00 \quad$ Lat 43049'I5", long 69055'I2", Harpswell, Maine, at Dyer's Cove, near house of John Dyer on the north side of the cove, excellent debris inside building transferred to a USGS high-water-mark disk (elev $9.42 \mathrm{ft}$ ) in the southeast corner of the fish house, I ft south of 0 white door, and about 14 in above the wharf. Tidal surge.

539.06 Lat 43047'I3", long 69056'04", Harpswell, Maine, at south end of Card's Cove on Great Island, excellent debris and ice line inside building transferred to a USGS high-water-mark disk (elev $9.76 \mathrm{ft}$ ) in the southwest corner of boathouse, $200 \mathrm{ft}$ northeast of the main house on Gun Point Road. The disk is near the door at floor level. Tidal surge.

$549.30 \quad$ Lat $43^{\circ} 47^{\prime} 40^{\prime \prime}$, long 69056'49", Harpswell, Maine, at the head of Orrs Island, excellent debris marked by a USGS high-water-mark disk (elev $16.55 \mathrm{ft}$ ) in the south side of pole 123 on east side of highwoy, $150 \mathrm{ft}$ southeast of centerline of bridge. Tidal surge.

$55 \quad 10.84 \quad$ Lat 43045'34", long 69058'25", Harpswell, Maine, Lowell Cove on Orrs Island, excellent ice and debris marked by a USCS high-water-mark disk on the southwest corner of David Johnson's wharf. Tidal surge.

$56 \quad 10.35$ Lat 43044'56", long 69059'32", Harpswell, Maine, on Bailey's Island, excellent ice and debris marked by a USGS high-water-mark disk (elev $14.32 \mathrm{ft}$ ) approximately $6 \mathrm{ft}$ above ground in pole 200/13 near Cooks Lobster House and near a pier to a fishhouse. Tidal surge. 
Table 1.-Flood data in Maine, New Hampshire, and Massachusetts (Continued)

Site Elevation

$(\mathrm{ft})$

Description

No.

$57 \quad 9.38$

Lat 4305l'29", long 69054'5l", Harpswell, Maine, excellent debris marked by red paint on west side of south abutment of State Route 24 bridge between Brunswick and Sebascodegan Island. Tidal surge.

589.38 Lat 4305I'56", long 69054'58", Brunswick, Maine, Buttermilk Cove, excellent debris marked by red paint on end of northwest wingwall of Prince Point Road bridge, about $1.5 \mathrm{ft}$ above ground, and $50 \mathrm{ft}$ east of Central Maine Power Co. pole 2. Tidal surge.

$599.02 \quad$ Lat 43046'39", long 70001'06", Harpswell, Maine, at the Naval Fuel Depot on Harpswell Neck, excellent debris marked by red paint (elev $9.35 \mathrm{ft}$ ) on shoreward side of the first pier $45 \mathrm{ft}$ shoreward of the main wharf, about I ft below the top of the concrete. Tidal surge.

$609.03 \quad$ Lat 43048'26", long 69059'39", Harpswell, Maine, near Lookout Point on Harpswell Neck, excellent wet line inside building transferred to a USGS high-water-mark disk (elev $9.36 \mathrm{ft}$ ) on the north face of Allen's Seafood fishhouse, approximately $2 \mathrm{ft}$ above the pier and 6 in from the northeast corner of the building. Tidal surge.

$619.02 \quad$ Lat 43052!06", long 69059'37", Brunswick, Maine, Wharton Point, excellent ice and debris marked by red paint on the concrete slab (second slab from top) in the wall around a l-ft-diameter drainage culvert near the upstream end of the twin culverts under the road. Tidal surge.

628.57 Lat 43051'48", long 70001'14", Brunswick, Maine, near Bunganuc Landing, excellent ice line inside building transferred to a USGS high-water-mark disk (elev $9.48 \mathrm{ft}$ ) approximately $1.5 \mathrm{ft}$ above the foundation and in the south wall of small house at end of road down Bunganuc Stream. Tidal surge.

639.33 Lat 43048'39", long 70006'08", Freeport, Maine, tip of Wolf's Neck, excellent ice and wash line marked by a USGS high-water-mark disk in a twin 5-in white-birch tree on the side of the cove opposite the high ground leading out to Pumpkin Knob, $30 \mathrm{ft}$ west of the wood stairway to the ledges and $200 \mathrm{ft}$ south of a blue house. Tidal surge.

649.08 Lat 4305/'25", long 70005'06", Freeport, Maine, at Mast Landing on Bow Street, excellent debris marked by a USGS high water-mark disk in a lone 27-in pine tree on east bank of Mill Stream, $100 \mathrm{ft}$ downstream from culvert and $120 \mathrm{ft}$ southeast of centerline of the road. Tidal surge. 
Table 1.--Flood data in Maine, New Hampshire, and Massachusetts (Continued)

\begin{tabular}{|c|c|c|}
\hline $\begin{array}{l}\text { Site } \\
\text { No. }\end{array}$ & $\begin{array}{c}\text { Elevation } \\
(\mathrm{ft})\end{array}$ & Description \\
\hline 65 & 9.26 & $\begin{array}{l}\text { Lat } 43^{\circ} 50^{\prime} 27^{\prime \prime} \text {, long } 70^{\circ} 06^{\prime} 0 l^{\prime \prime} \text { Freeport, Maine, at Porter Landing, } \\
\text { excellent ice and debris marked by two USGS high-water-mark disks } \\
\text { in the front, seaward corner of the Regatta Yacht Club building, } \\
\text { near where a metal pipe fence connects onto the building. Lower } \\
\text { disk is } 2-7-78 \text { high-water mark (elev } 9.26 \mathrm{ft} \text { ); upper disk is } 1-9.78 \\
\text { high-water mark (elev } 10.03 \mathrm{ft} \text { ). Tidal surge. }\end{array}$ \\
\hline 66 & 8.90 & $\begin{array}{l}\text { Lat } 43^{\circ} 48^{\prime} 44^{\prime \prime} \text {, long } 70^{\circ} 09^{\prime} \mid 2^{\prime \prime} \text {, Yarmouth, Maine, excellent salt line } \\
\text { marked by red paint on the upstream headwall of the southbound } \\
\text { Interstate I-95 bridge over Cousins River, just east of the Granite } \\
\text { Road intersection. The mark is } 5 \mathrm{ft} \text { streamward of the west } \\
\text { abutment. Tidal surge. }\end{array}$ \\
\hline 67 & 10.23 & $\begin{array}{l}\text { Lat } 43047 \cdot 52 " \text {, long } 700^{\prime} 35 " \text {, Yarmouth, Maine, excellent ice line } \\
\text { marked by red paint on southeast side of State Route } 88 \text { bridge over } \\
\text { Royal River, } 50 \mathrm{ft} \text { from the centerline of the river, } 8 \mathrm{ft} \text { from the } \\
\text { corner of the abutment and approximately } 4 \mathrm{ft} \text { above the bottom of } \\
\text { the arch of the bridge opening. Tidal surge. }\end{array}$ \\
\hline 68 & 9.36 & $\begin{array}{l}\text { Lat } 43045^{\prime} / 4^{\prime \prime} \text {, long } 70^{\circ} 08 \text { ' } 31 " \text {, Yarmouth, Maine, Cousins Island, at } \\
\text { the parking lot for the Chebeague Island Ferry. Excellent debris ond } \\
\text { wash line marked by a USGS high-water-mark disk in the first cedor } \\
\text { fencepost from the end, at the lower end of the parking lot, and } \\
\text { approximately } 5 \text { in below the lower fence rail. Tidal surge. }\end{array}$ \\
\hline 69 & 9.40 & $\begin{array}{l}\text { Lat } 43^{\circ} 4^{\prime} 08^{\prime \prime} \text { long } 70^{\circ} 09^{\prime} 27 " \text { ", Yarmouth, Maine, at Cousins Island } \\
\text { steamplant. Excellent ice and debris line marked by a USCS } \\
\text { high-water-mark disk I ft above the bottom hinge in the doorframe } \\
\text { to the buoy shack at the bottom of the ramp leading down from the } \\
\text { wharf and at the top of a second ramp leading to a floating boot } \\
\text { dock, on the southwest side of the wharf out to the main pier. Tidal } \\
\text { surge. }\end{array}$ \\
\hline 70 & 9.48 & $\begin{array}{l}\text { Lat } 43043 \text { '30", long } 70^{\circ} 3^{\prime} 29^{\prime \prime} \text {, Falmouth, Maine, excellent debris and } \\
\text { wash line marked by red paint on northwest wingwall of arch-type } \\
\text { bridge over Mill Creek, I mi southwest of Falmouth Foreside on } \\
\text { State Route } 88 \text {. The mark is approximately } 6 \text { in above the base wall } \\
\text { on which the arch sets. Tidal surge. }\end{array}$ \\
\hline 71 & 9.68 & $\begin{array}{l}\text { Lat } 43^{\circ} 42^{\prime} 57^{\prime \prime} \text {, long } 70^{\circ} 5^{\prime} \mid 2^{\prime \prime} \text {, Falmouth, Maine, excellent debris and } \\
\text { wash line marked by a USGS high-water-mark disk in a } 7 \text {-in elm tree } \\
\text { at the northeast end of the State Route } 9 \text { bridge over the } \\
\text { Presumpscot River, near a group of six 10-in willow trees, and } 70 \text { ft } \\
\text { toward the river from Central Maine Power Co. pole } 167 \text {. Tidol } \\
\text { surge. }\end{array}$ \\
\hline
\end{tabular}


Table 1.--Flood data in Maine, New Hampshire, and Massachusetts (Continued)

\begin{tabular}{|c|c|c|}
\hline $\begin{array}{l}\text { Site } \\
\text { No. }\end{array}$ & $\begin{array}{c}\text { Elevation } \\
(\mathrm{ft})\end{array}$ & Description \\
\hline 72 & 9.55 & $\begin{array}{l}\text { Lat } 43040^{\prime} 40^{\prime \prime} \text {, long } 70^{\circ} 15^{\prime} 19 " \text { ", Portland, Maine, at Burnham and } \\
\text { Morrill Canning Factory, excellent debris line marked by red paint } \\
\text { on seventh post of link fence west from the fence corner near the } \\
\text { main factory building. The post is } 70 \mathrm{ft} \text { south of a flagpole and the } \\
\text { red mark is about I } \mathrm{ft} \text { above the seawall west of the factory. Tidal } \\
\text { surge. }\end{array}$ \\
\hline 73 & 9.91 & $\begin{array}{l}\text { Lat } 43^{\circ} 39^{\prime} 58^{\prime \prime} \text {, long } 70^{\circ} 16^{\prime} \mid 8^{\prime \prime} \text {, Portland, Maine, Back Cove, excellent } \\
\text { wash line marked by red paint on top of concrete casing for manhole } \\
\text { cover near south exit of Baxter Boulevard, } 45 \mathrm{ft} \text { north of street light } \\
\text { pole } 06 \text {, and } 60 \mathrm{ft} \text { east of centerline of U.S. Route I. Tidal surge. }\end{array}$ \\
\hline $74 \mathrm{~A}$ & 9.6 & $\begin{array}{l}\text { Lat } 43^{\circ} 40^{\prime} \text {, long } 70^{\circ} 5^{\prime} \text {, Portland, Maine, National Ocean Survey tide } \\
\text { gage. Water-surface elevation furnished by National Ocean Survey. } \\
\text { Tidal surge. }\end{array}$ \\
\hline
\end{tabular}

7489.43 Lat 43039'20", long 70'15'03", Portland, Maine, Maine Wharf, excellent wet line inside building transferred to a USGS high-water-mark disk in bottom section of shelving structure near the east wall of the inside of the Brown Ship Chandlery warehouse. The disk is approximately 2 to 3 in above the concrete. Tidal surge.

$74 \mathrm{C} 9.45$ Lat 43039'20", long 70ㅇ' 03 ", Portland, Maine, Maine Wharf, west side, excellent ice line marked by a USGS high-water-mark disk in the support post near the center of the wharf and just west of the loading door to the Brown Ship Chandlery warehouse. Tidal surge.

$759.84 \quad$ Lat $43^{\circ} 38^{\prime} 53^{\prime \prime}$, long $70^{\circ}$ I5' $^{\prime} 6$ ", Portland, Maine, Deaks Wharf (the first wharf east of the Portland Bridge), excellent debris line marked by a USGS high-water-mark disk in the recently replaced support post near the north edge of the silver colored fishhouse on the wharf. Tidal surge.

$76 \quad 9.39$ Lat 43039'3l", long 70018'44", Portland, Maine, excellent ice and wash line marked by red paint on the bottom of the second concrete block from the top of the foundation, near the center of the west side of Forest City Rod and Gun Club building. The building is near the first State Route 9 bridge north of Stroudwater River. Tidal surge.

$77 \quad 10.24 \quad$ Lat 43038' $4 l^{\prime \prime}$, long 70017'32", South Portland, Maine, excellent debris marked by red paint on the rock work under the southbound Interstate 1-295 bridge over the bay. Mark is under centerline of road and approximately $9.0 \mathrm{ft}$ below the low steel of the bridge. Tidal surge. 
Table 1.--Flood data in Maine, New Hampshire, and Massachusetts (Continued)

\begin{tabular}{ccl}
\hline $\begin{array}{l}\text { Site } \\
\text { No. }\end{array}$ & $\begin{array}{c}\text { Elevation } \\
(\mathrm{ft})\end{array}$ & \multicolumn{1}{c}{ Description } \\
\hline 78 & 10.09 & $\begin{array}{l}\text { Lat } 43^{\circ} 38^{\prime} \mid 9^{\prime \prime}, \text { long } 70^{\circ} \mid 5^{\prime} 28^{\prime \prime} \text {, South Portland, Maine, at sewerage. } \\
\text { treatment facility, excellent wash line marked by red paint on the } \\
\text { northwest corner of concrete wall just north of gate to the discharge } \\
\text { pipe. The mark is } 4.3 \mathrm{ft} \text { below the top of the concrete wall and } \\
\text { approximately } 0.4 \mathrm{ft} \text { below a blue chalk line (presumed to be o } \\
\text { backfill line). Tidal surge. }\end{array}$
\end{tabular}

$79 \quad 10.25 \quad$ Lat 43038'43", long 70914'57", South Portland, Maine, U.S. Coost Guard facility, excellent ice and debris line marked by a USGS high-water-mark disk on the west side of a support post near the most easterly landing on the south side of the most southerly pier, and near the ramp to a floating boat dock. Tidal surge.

80. 5.67 Lat 43038'35", long 70013'43", South Portland, Maine, at Simonton Cove, good ice and debris line marked by a USGS high-water-mark disk 6.0 in above sill of seaward cellar window on north side of the red house at 10 Myrtle Avenue. Elevation is approximately that of the third step to the sundeck on the seaward side of the house. NOTE: Disk gone at time of survey. Based on description, three elevations are possible: 6 in above sill $=5.67 \mathrm{ft}$; nail hole in window frame $=5.57 \mathrm{ft}$; third step to sundeck $=6.14 \mathrm{ft}$. Tidal surge.

$81 \quad 10.60 \quad$ Lat 43036'3l", long 70013'05", Cape Elizabeth, Maine, at Pond Cove, excellent ice and wash line marked by a USGS high-water-mark disk in the base of an 18-in maple tree, one of a group of four maples, $150 \mathrm{ft}$ west of the centerline of Shore Road, $100 \mathrm{ft}$ south of centerline of a swamp and $50 \mathrm{ft}$ southwest of the two-car garage at 1107 Shore Road. Tidal surge.

$828.59 \quad$ Lat 43034'57", long 70015'29", Scarborough, Maine, excellent ice and debris line marked by red paint on top of the nut holding the center support pole to the abutment retaining wall on the northwest side of the State Route 77 bridge over Spurwink River. The nut is approximately $1.0 \mathrm{ft}$ below the low steel of the bridge. Tidal surge.

$83 \quad 10.22$ Lat 43033'40", long 70016'39", Scarborough, Maine, Higgins Beach, good debris line in building transferred to a USGS high-water-mark disk (elev $11.22 \mathrm{ft}$ ) set in New England Telephone and Telegraph pole 5 on the southwest corner of the intersection of Ocean Drive and Vesper Street. Mark was transferred from red log cabin on the northeast corner of the intersection, about $1-1 / 2$ blocks below the sill on the foundation. Wave action. 
Table 1.--Flood data in Maine, New Hampshire, and Massachusetts (Continued)

Site Elevation

$(f t)$

Description

No.

9.75

Lat 43032'36", long 70019'2l", Scarborough, Maine, Prouts Neck, good debris line in building transferred to a USGS high-water-mark disk set in the southwest corner of Prouts Neck Association red boathouse. Boathouse is on Ferry Road, just past the Prouts Neck Golf Course on the back shore. The boathouse is the southernmost of the two buildings and the mark is $2.0 \mathrm{ft}$ above the sill. Tidal surge.

Lat 43032'33", long 70020'46", Scarborough, Maine, fair debris line in building transferred to a USGS high-water-mark disk set on Central Maine Power Co. pole 123.I. This is the service pole to Pine Point Seafood Market on the north side of State Route 9 and across the street from Pine Point Church, $0.3 \mathrm{mi}$ southeast along Pine Point Road (State Route 9) from Jones Creek. Tidal surge.

Lat 43030'56", long 70022'26", Old Orchard Beach, Maine, fair debris line in building transferred to a USGS high-water-mark disk set in New England Telephone and Telegraph pole with a phone booth attached, located about $100 \mathrm{ft}$ to the west of Old Orchard Beach Pier, on the north side of Main Street. Wave action.

Lat 43029'52", long 70023'l8", Old Orchard Beach, Maine, good debris line in building transferred to a USGS high-water-mark disk set on New England Telephone and Telegraph pole 68 in front of Old Orchard Beach Sewerage Pumping Station on west side of State Route 9, $100 \mathrm{ft}$ north of the Saco-Old Orchard Beach Town Line and Goosefare Brook. Tidal surge.

$88 \quad 10.18$

Lat 43029'32", long 70026'50", Biddeford, Maine, at the Biddeford Water Pollution Control Plant on left bank of Saco River about $0.2 \mathrm{mi}$ southeast of Factory Island. Excellent oil slick exactly $3.0 \mathrm{ft}$ below the top of the concrete retaining wall surrounding the clarifier as measured from the southeasternmost wall. Tidal surge.

Lat 43027'5l", long 70022'56", Saco, Maine, Camp Ellis, good debris line in building transferred to a USGS high-water-mark disk (elev 12.0l ft) set in Central Maine Power Co. pole J-3 on east side of North Avenue just across street from Dube's Bait and Tackle Shop. Disk is $2.00 \mathrm{ft}$ higher than the high-water mark. Tidal surge.

$90 \quad 9.81 \quad$ Lat 43026'47", long 70021'19", Biddeford, Maine, Biddeford Pool, good debris line in building transferred to a USGS high-water-mark disk set in Central Maine Power Co. pole 9 on south side of intersection near "The Lodge" and the rear of Crowley's Lobster Pound, past Fletcher Neck on State Route 208 going toward the narrows separating Biddeford Pool and Fort Hill. Tidal surge. 
Table I.-Flood data in Maine, New Hampshire, and Massachusetts (Continued)

\begin{tabular}{ccl}
\hline $\begin{array}{c}\text { Site } \\
\text { No. }\end{array}$ & $\begin{array}{c}\text { Elevation } \\
(\mathrm{ft})\end{array}$ & \multicolumn{1}{c}{ Description } \\
\hline 91 & 13.34 & $\begin{array}{l}\text { Lat } 43^{\circ} 25^{\prime} 27^{\prime \prime}, \text { long } 70^{\circ} 22^{\prime} 43^{\prime \prime}, \text { Biddeford, Maine, Fortunes Rocks, } \\
\text { fair debris line in building transferred to a USGS high-water-mark }\end{array}$ \\
& & $\begin{array}{l}\text { disk set in Central Maine Power Co. pole to west and coming from } \\
\text { Central Maine Power Co. pole 36-J45, on State Route } 9 \text { just north of }\end{array}$ \\
& Wilbur residence, 0.2 mi south of Etherington Pond. Wave action.
\end{tabular}

$92 \quad 10.20$ Lat $43^{\circ} 24^{\prime} 02^{\prime \prime}$, long $70^{\circ} 25^{\prime} \mid 8^{\prime \prime}$, Kennebunkport, Maine, good salt line in building transferred to a USGS high-water-mark disk set in Central Maine Power Co. pole 104-J6 just west of Chip's Ploce Restaurant, $100 \mathrm{ft}$ west of Smith Brook on Rocks Road, $0.4 \mathrm{mi}$ southeast along Rocks Road from the Clock Farm Corner. Tidol surge.

$93 \quad 10.47$ Lat $43^{\circ} 22^{\prime} 07^{\prime \prime}$, long $70^{\circ} 26^{\prime} 44^{\prime \prime}$, Kennebunkport, Maine, good debris line in building transferred to a USGS high-water-mark disk set in Central Maine Power Co. pole $300-J-1 / 2200 \mathrm{ft}$ east of Wildes District Road on first side street after crossing Paddy Creek, $0.2 \mathrm{mi}$ southwest of junction of Wildes District Road and State Route?. Tidal surge.

$94 \quad 10.29$ Lat 43021'04", long 70028'23", Kennebunkport, Maine, good salt line in building transferred to a USGS high-water-mark disk set in easternmost roadside porch corner post of private building on piers over the water, on south side of Ocean Avenue about $300 \mathrm{ft}$ west of Simpson's Antiques, and $0.75 \mathrm{mi}$ east of the intersection of Ocean Avenue and State Route 9. Tidal surge.

Lat 43019'19", long 70033'24", Wells, Maine, Drakes Island, good sand line in building transferred to a USGS high-water-mark disk (elev $11 . I \mathrm{ft}$ ) set in base of Central Maine Power Co. pole 4 just south of the southernmost house on Drakes Island. Wave action.

$96 \quad 9.79 \quad$ Lat 43017'40", long 70034'07", Wells, Maine, Wells Beach, good salt line in building transferred to a USGS high-water-mark disk set in west side of Central Maine Power Co. pole J-13-105 on Webhannet Drive, about $500 \mathrm{ft}$ north of Fisherman's Cove in front of the new pumping station for sewer lines under construction on Wells Beach. Wave overwash.

$97 \quad 13.74$ Lat 430l4'll", long 70035'25", Ogunquit, Maine, excellent salt line in building transferred to a USGS high-water-mark disk set $3.8 \mathrm{ft}$ above floor of wharf in the northwesternmost of four supporting hoist posts at the public wharf northwest of footbridge crossing Perkins Cove, Salt line marked and observed by several fishermen. Tidal surge. 
Table 1.-Flood data in Maine, New Hampshire, and Massachusetts (Continued)

\begin{tabular}{|c|c|c|}
\hline $\begin{array}{l}\text { Site } \\
\text { No. }\end{array}$ & $\begin{array}{c}\text { Elevation } \\
(\mathrm{ft})\end{array}$ & Description \\
\hline 98 & 10.95 & $\begin{array}{l}\text { Lat } 43^{\circ} \mid I^{\prime} 17 " \text { ", long } 70^{\circ} 36^{\prime} 22^{\prime \prime} \text {, York, Maine, good debris line in } \\
\text { building transferred to a USGS high-water-mark disk set just above } \\
\text { ground level in the northeast corner of the Cape Neddick Lobster } \\
\text { Pound, } 100 \mathrm{ft} \text { southwest of bridge over Cape Neddick River on Shore } \\
\text { Road. Tidal surge. }\end{array}$ \\
\hline
\end{tabular}

9911.63 Lat 43009'44", long 70037'14", York, Mcine, Long Beach, fair sand line in building transferred to a USGS high-water-mark disk (elev $13.63 \mathrm{ft}$ ) set $0.5 \mathrm{ft}$ above ground in west side of Central Maine Power Co. pole I0I on north side of intersection of Long Beach Avenue and Beacon Street. Wave action and overwash.

$100 \quad 10.08 \quad$ Lat 43008'02", long 70038'53", York, Maine, good debris line in building transferred to a USGS high-water-mark disk set Ift above concrete base of electrical meter support post on the south end of York Town Wharf no. I located on the north side of Bragdon Island to the southeast of the bridge over York River. Tidal surge.

101 $\quad 9.78$ Lat 43005'08", long 70040'56", Kittery, Maine, good salt line marked by a USGS high-water-mark disk in the southeast corner of the Robert Withum Workshop located behind the second house to the northeast of bridge on Pocahontah Road over Chauncey Creek, on the right bank. Tidal surge.

1027.34 Lat 43002'I3", long 70055'20", Rockingham, N.H., good mark, nail, green flag in pole 724 on downstream side culvert of Jewell Hill Brook on road off State Route 108, $0.3 \mathrm{mi}$ south of bridge over Squamscott River. Tidal surge.

$1036.41 \quad$ Lat 43003'27", long 70050'04", Greenland Station, N.H., good mark, nail, flag in oak tree at shoreline approximately $240 \mathrm{ft}$ north of north edge of parking area, $0.3 \mathrm{mi}$ west off Newington Road, $0.55 \mathrm{mi}$ north off Portsmouth Avenue. Ice cover on bay, no wind effect; tidal surge.

$104 \quad 6.6$ Lat 43005'33", long 70051'55", Durham, N.H., good debris marks on wooden walkway at pier at University of New Hampshire oceanography building. Ink mark with nailed red flag, $0.2 \mathrm{mi}$ north of Adams Point at Little Bay. Tidal surge.

$105 \quad 6.93$ Lat 43008'06", long 70054'53", Durham, N.H., good wet line marked by nail, flag, ink line, on downstream side of Littlehole Creek culvert on State Route 108, $0.25 \mathrm{mi}$ southwest of junction of U.S. Route 4 and State Route 108. Tidal surge. 
Table 1.-Flood data in Maine, New Hampshire, and Massachusetts (Continued)

\begin{tabular}{|c|c|c|}
\hline $\begin{array}{l}\text { Site } \\
\text { No. }\end{array}$ & $\begin{array}{c}\text { Elevation } \\
(\mathrm{ft})\end{array}$ & Description \\
\hline 106 & 7.2 & $\begin{array}{l}\text { Lat } 43^{\circ} 07{ }^{\prime} 49 " \text { ", long } 7005 I^{\prime} I I " \text {, Durham, N.H., good debris lines, ink } \\
\text { line, flag, nail at base of large double hickory tree on U.S. Routes } \\
\text { at Cedar Point on Durham end of Scammel Bridge. Tidal surge. }\end{array}$ \\
\hline 107 & 7.68 & $\begin{array}{l}\text { Lat } 43^{\circ} 06^{\prime} 57^{\prime \prime} \text {, long } 70^{\circ} 50^{\prime} I 0^{\prime \prime} \text {, Newington, N.H., excellent silt line, } \\
\text { nail, flag, on end of shore pier for floating dock at Great Boy } \\
\text { Marina, } 0.5 \mathrm{mi} \text { north of Fox Point Road at east end of Broad Cove, } \\
\text { Tidal surge. }\end{array}$ \\
\hline 108 & 7.73 & $\begin{array}{l}\text { Lat } 43007 \text { 'I", long } 7004914 l^{\prime \prime} \text {, Dover, N.H., good debris line and sot } \\
\text { mark at base of guardrail post marked by ink and nailed red flag of } \\
\text { Hilton State Park off northbound lane of State Route } 16 \text { in Dover, } \\
\text { Tidal surge. }\end{array}$ \\
\hline 109 & 8.78 & $\begin{array}{l}\text { Lat } 43^{\circ} 05^{\prime} 02^{\prime \prime} \text {, long } 704^{\prime} 5^{\prime} 00^{\prime \prime} \text {, Kittery, Maine, good debris line } \\
\text { marked by a USGS high-water-mark disk in the northeast corner of } \\
\text { the easternmost garage next to Warren's Restaurant, on the } \\
\text { northeast side of the old U.S. Route I bridge over the Piscatoqu } \\
\text { River near Badgers Island. Tidal surge. }\end{array}$ \\
\hline 110 & 9.21 & $\begin{array}{l}\text { Lat } 43^{\circ} 04^{\prime} \mid 8^{\prime \prime} \text {, long } 70^{\circ} 43^{\prime} 56^{\prime \prime} \text {, New Castle, N.H., good ice ring o } \\
\text { pole verified by surrounding debris lines, marked by nail, green flog } \\
\text { in pole } 68 \text { (second pole from west end of causeway) on New Costle } \\
\text { Avenue between Goat Island and Shaws Hill. Road flooded by a few } \\
\text { inches. Tidal surge. }\end{array}$ \\
\hline III & 10.36 & $\begin{array}{l}\text { Lat } 43^{\circ} 04^{\prime} 06^{\prime \prime} \text { long } 70^{\circ} 43^{\prime} 01 " \text {. New Castle, N.H., fair snow line, noil, } \\
\text { green flag in } 14 \text {-in willow tree } 50 \mathrm{ft} \text { east of New Castle Avenue, } 15 \mathrm{ft} \\
\text { behind ivory-colored garage, I,000 ft south of northern shore front of } \\
\text { New Castle. Road flooded. Cause of flooding uncertain. }\end{array}$ \\
\hline 112 & 8.04 & $\begin{array}{l}\text { Lat } 43003^{\prime} 06^{\prime \prime} \text {, long } 70046^{\prime} 20^{\prime \prime} \text {, Portsmouth, N.H., good line of ice } \\
\text { cakes on bank and salt line on outside of restaurant transferred to } \\
\text { New England Telephone and Telegraph pole } 3102 \mathrm{~J} 3 \text {. Ink line with } \\
\text { nailed red flag at high-water mark, off southbound lane of U.S. } \\
\text { Route I, O.I mi west of U.S. Route I on the north side of Sagamore } \\
\text { Creek. Water } 6 \text {-in deep in Bratskellar dining room on south bank of } \\
\text { creek. Tidal surge. }\end{array}$ \\
\hline 113 & 8.36 & $\begin{array}{l}\text { Lat } 43^{\circ} 03^{\prime} \text { II", long } 70044^{\prime} 30^{\prime \prime} \text {, Foyes Corner, N.H., good snow line } \\
\text { nail, green flag in pole } 710 \text {, } 75 \mathrm{ft} \text { northwest of southern end of New } \\
\text { Castle Avenue, } 0.35 \mathrm{mi} \text { from junction with U.S. Route IA. Tidal surge. }\end{array}$ \\
\hline 114 & 9.38 & $\begin{array}{l}\text { Lat } 43^{\circ} 02^{\prime} 36^{\prime \prime} \text {, long } 70^{\circ} 4^{\prime} 07 " \text { ", Foyes Corner, N.H., good salt mark, } \\
\text { nail, red flag on tree, on right upstream side of Berrys Brook culvert } \\
\text { on Brackett Road, } 500 \mathrm{ft} \text { south of Pioneer Road (U.S. RoutelA), } \\
\text { Tidal surge. }\end{array}$ \\
\hline
\end{tabular}


Table 1.-Flood data in Maine, New Hampshire, and Massachusetts (Continued)

Site Elevation

No. $(\mathrm{ft})$

Description

II5 $8.84 \quad$ Lat 43002'54", long 70043'3I", Fort Dearborn, N.H., good ice rings on pole verified by debris lines in adjacent field, nail, red flag on post off Pioneer Road (U.S. Route IA) opposite west entrance to Fort Dearborn, about $300 \mathrm{ft}$ south of road. Tidal surge.

$\| 6 \quad 8.36$

Lat 43001'56", long 70044'l0", Fairhill Manor, N.H., good salt marks, nail, red flag on trees on south side of Clark Road near junction with Marsh Road. Tidal surge.

$\| 7 \quad 7.99 \quad$ Lat 43001'50", long 70043'53", Fairhill Manor, N.H., good salt marks, 7.73 nail, green flag in each of three trees along Marsh Road at fork of 7.36 road by cemetery, about $900 \mathrm{ft}$ northwest of junction of U.S. Route IA and Marsh Road. Tidal surge.

118 9.91 Lat 43001'08", long 70044'4l", Rye North Beach, N.H., fair salt

9.81 marks, nail, red flag on tree on west side of Brackett Road, $0.35 \mathrm{mi}$ north of Washington Road. Two elevations obtained. Cause of flooding uncertain.

$119 \quad 8.53 \quad$ Lat 43000'49", long 70044'42", Rye North Beach, N.H., good ice rings in field transferred to nail, red flag in fencepost in northeast corner of junction of Brackett Road and Washington Road, about $300 \mathrm{ft}$ from either road. Tidal surge.

$120 \quad 11.65 \quad$ Lat 43000'll", long 70044'59", Rye Harbor, N.H., good salt and ice marks verified by debris line in field, nail, red flag on pole at south side of Ocean Boulevard bridge, $0.2 \mathrm{mi}$ west of bend in road at Ragged Point Neck. Wave bore.

|2| -- Deleted, data erroneous.

$122 \quad$ Lat 42059'59", long 70045'20", Rye Harbor, N.H., mean of several fair salt marks marked by nail, flag on tree on U.S. Route IA, $0.3 \mathrm{mi}$ north of Locke Road, opposite home of Mrs. Goss. Wave bore.

Lat 42059'22", long 70045'33", Cable Road, N.H., good salt marks, nail, flag in tree at 100 Locke Road. Pole in front of 100 Locke Road is $5.25 \mathrm{ft}$ above high-water mark. Wave bore.

$124 \quad 6.39 \quad$ Lat 42059'05", long 70045'50", Rye Beach, N.H., good high-water marks in pond area transferred to nail (elev 12.39 ft) in pole 23-7-32 (third pole south of Dunes Motel) on U.S. Route IA at northerly side of Eel Pond. Tidal surge. Culvert may have restricted inflow.

7.72 Lat 42058'15", long 70046'29", Bass Beach, N.H., red flag at ice rings on trees off Central Road, $0.5 \mathrm{mi}$ north of intersection of Central Road and Chapel Road. Tidal surge. 
Table 1.-Flood data in Maine, New Hampshire, and Massachusetts (Continued)

\begin{tabular}{|c|c|c|}
\hline $\begin{array}{l}\text { Site } \\
\text { No. }\end{array}$ & $\begin{array}{c}\text { Elevation } \\
(\mathrm{ft})\end{array}$ & Description \\
\hline 126 & $\begin{array}{l}8.04 \\
8.02\end{array}$ & $\begin{array}{l}\text { Lat } 42^{\circ} 58^{\prime} 02^{\prime \prime} \text {, long } 70^{\circ} 46^{\prime} 38^{\prime \prime} \text {, Bass Beach, N.H., red flag at good ice } \\
\text { rings on trees off Central Road I, } 300 \mathrm{ft} \text { north of intersection of } \\
\text { Central Road and Chapel Road. Tidal surge. }\end{array}$ \\
\hline 127 & 7.68 & $\begin{array}{l}\text { Lat } 42057 \cdot 37 " \text {, long } 70046 ' 20^{\prime \prime} \text {, Bass Beach, N.H., several good ice } \\
\text { cakes and debris lines marked at culvert on U.S. Route IA, } 0.6 \mathrm{mi} \\
\text { north of intersection of State Route IOID. Cause of flooding } \\
\text { uncertain. }\end{array}$ \\
\hline
\end{tabular}

I28 $7.79 \quad$ Lat 42057'53", long 70047'47", North Hampton, N.H., red flag at good ice rings on trees $500 \mathrm{ft}$ north of intersection of Woodland Road and State Route I0ID. Tidal surge.

I29 8.18 Lat 42057'26", long 70046'48", North Hampton, N.H., good debris marks in area transferred to "X" mark on top of concrete abutment on right upstream wall at junction of Sea Road and Ocean Boulevard South. Overwash and entrapment of water.

$130 \quad 7.95$ Lat 42057'll", long 70047'I0", North Hampton, N.H., Appledore Avenue, edge of fair snow and ice line is top of culvert header, upstream side of culvert, about $50 \mathrm{ft}$ off U.S. Route IA. Overwash and entrapment of water.

I3I $8.40 \quad$ Lat 42055'28", long 7005I'I3", Hampton Falls, N.H., good salt mark on Lafayette Road at right, upstream edge of bridge over Taylor River. Ink mark on sign post across road from Jerry's Restaurant and Lobster Pond, on Lafayette Road, three-quarters of a mile northeast of Hampton Falls. Tidal surge.

I32 $7.70 \quad$ Lat 42054'4l", long 7005I'08", Hampton Falls, N.H., Depot Avenue, at end of dead end road. Good high-water marks in area transferred to mark on steel post of crossing sign (elev $11.60 \mathrm{ft}$ ). Tidal surge.

I33 8.63 Lat 42055'28", long 70050'II", Hampton Landing, N.H., fair ice marks marked by "X" on concrete base of statue marked Herbert $L$. Whitney at "Hampton River Boat Club", southwest of landing road (off State Route 51) at edge of tidal channel. Wave bore.

$1347.03 \quad$ Lat 42056'28", long 70048'02", Hampton, N.H., North Beach, fair ice flow marks in swamp transferred to nail in swamp mapie on left downstream side of culvert $50 \mathrm{ft}$ downstream on State RoutelolC where Old Mill Pond flows into Meadow Pond. Overwash and entrapment of water. 
Table I.--Flood data in Maine, New Hampshire, and Massachusetts (Continued)

\begin{tabular}{|c|c|c|}
\hline $\begin{array}{l}\text { Site } \\
\text { No. }\end{array}$ & $\begin{array}{c}\text { Elevation } \\
(\mathrm{ft})\end{array}$ & Description \\
\hline 135 & 7.85 & $\begin{array}{l}\text { Lat } 42^{\circ} 55^{\prime} 38^{\prime \prime} \text {, long } 70^{\circ} 48^{\prime} 04^{\prime \prime} \text {, Hampton, N.H., good ice marks on } \\
\text { motel lawn transferred to black mark near base of New England } \\
\text { Telephone and Telegraph pole } 510-559-580 \text { on white painted part, } \\
\text { across street from Ocean Motel on State Route I0IE, } 400 \mathrm{ft} \text { west of } \\
\text { junction of U.S. Route IA. Cause of flooding uncertain. }\end{array}$ \\
\hline
\end{tabular}

$136 \quad 8.27$ Lat 42054'58", long 70048'48", Hampton Beach, N.H., on Church Street (State Route 5I), good ice marks, ink and red flag near base of green fence on swamp side of Hampton water tower near substation. Tidal surge.

$137 \quad 7.83$

Lat 42055'2l", long 70049'25", Hampton Landing, N.H., good ice ring, nail and ink marks in pole (underground cable pole) on right, upstream side bridge over Mill Creek on Hampton Expressway (State Route 5I). Tidal surge.

$138 \quad 7.67$ Lat $42^{\circ} 55^{\prime} 17 "$ ", long $70^{\circ} 49^{\prime} 26^{\prime \prime}$, Hampton Landing, N.H., good ice rings and salt mark, nail and ink marks on pole 3353 on Hampton Expressway (State Route 5I) on left, downstream side Mill Creek culvert. Tidal surge.

$1399.73 \quad$ Lat 42054'37", long 70049'32", Hampton, N.H., The Willows, fair sal $t$ ring, nail, flag in 8-in post at end of road to The Willows. Post in center of roadway end. Wave bore.

$140 \quad 9.17 \quad$ Lat $42^{\circ} 5^{\prime} 07 "$ ", long $70^{\circ} 4^{\prime} 09^{\prime \prime}$, Hampton Beach, N.H., good ice ring, roofing nail on first post just below steps down to the last dock at end of road, $0.3 \mathrm{mi}$ north of Locke Point. Wave bore.

141 8.91 Lat 42054'00", long 70050'45", Seabrook, N.H., good ice ring, nail, green flag in oak tree $50 \mathrm{ft}$ north of dirt construction road (Rocks Road) at a point opposite steel bulkhead at main construction site, I mi from guard station at entrance. Tidal surge.

$142 \quad 9.13$ Lat $42^{\circ} 53^{\prime} 59^{\prime \prime}$, long $70050^{\prime} 35^{\prime \prime}$, Seabrook, N.H., good ice line, flag on sign "Blasting Area" $0.2 \mathrm{mi}$ east of extreme easterly end of Rocks Road, 1.5 mi east of U.S. Route I. Tidal surge.

1439.37 Lat 42053'02", long 70050'52", Seabrook, N.H., good frost line on bridge abutment transferred to nail, green flag in top of old post (telephone pole) on east side of Causeway Road, $40 \mathrm{ft}$ north of north end of guard rail on bridge. Wave bore or tidal surge.

1449.94 Lat 42053'l 8 ", long 70050'46", Seabrook, N.H., fair snow line, nail, green flag in small post $20 \mathrm{ft}$ east of apple tree near last light pole at end of Depot Road. Complete ice cover in bay. Cause of flooding uncertain. 
Table 1.--Flood data in Maine, New Hampshire, and Massachusetts (Continued)

\begin{tabular}{|c|c|c|}
\hline $\begin{array}{l}\text { Site } \\
\text { No. } \\
\end{array}$ & $\begin{array}{c}\text { Elevation } \\
(\mathrm{ft})\end{array}$ & Description \\
\hline 145 & 6.7 & $\begin{array}{l}\text { Lat } 42^{\circ} 50^{\prime} 35^{\prime \prime} \text {, long } 70^{\circ} 5 I^{\prime} 15^{\prime \prime} \text {, Salisbury, Mass., good snow ring, nail, } \\
\text { flag in pole } 12 \mathrm{I} \text {, small powerline from end of unnamed road opposite } \\
54 \text { Beach Road near Wonder Potato Chip factory ( } 0.4 \mathrm{mi} \text { east of } \\
\text { Salisbury off U.S. Route IA), across small valley; first pole beyond } \\
\text { end of road. Mark is at least } 1.5 \mathrm{ft} \text { above ground surface. Tidal } \\
\text { surge. }\end{array}$ \\
\hline 146 & 7.34 & $\begin{array}{l}\text { Lat } 42^{\circ} 50^{\prime} 32^{\prime \prime} \text {, long } 70^{\circ} 50^{\prime} 59^{\prime \prime} \text {, Salisbury, Mass., good snow line, nail } \\
\text { and flag } 2 \mathrm{ft} \text { above base of } 14 \text {-in maple tree about } 100 \mathrm{ft} \text { northeast of } \\
\text { end of Meaders Lane, } 0.3 \mathrm{mi} \text { off U.S. Route IA (Beach Road). Tidal } \\
\text { surge. }\end{array}$ \\
\hline 147 & 9.27 & $\begin{array}{l}\text { Lat } 42^{\circ} 50^{\prime} 33^{\prime \prime} \text {, long } 70^{\circ} 49^{\prime} 3 I^{\prime \prime} \text {, Salisbury Beach, Mass., good debris } \\
\text { line in area transferred to nail, green flag on pole } 56 / 35 \text { (third pole } \\
\text { north of U.S. Route IA) on west side of County Road, } 300 \mathrm{ft} \text { north of } \\
\text { U.S. Route IA. County Road inundated in this area. Cause of high } \\
\text { elevation uncertain. }\end{array}$ \\
\hline
\end{tabular}

$148 \quad 7.84 \quad$ Lat 42050'39", long 70049'36", Salisbury Beach, Mass., good ice line, nail, green flag on pole 28 (between two small camps) on south side of County Road $0.2 \mathrm{mi}$ north of U.S. Route IA. Foundation posts were wetted. Tidal surge.

$149 \quad 7.60 \quad$ Lat 42051'19", long 70049'13", Salisbury Beach, Mass., good ice ring, nail, green flag on pole 4 (next to last pole) on west end of Liberty Street off North Boulevard, 0.9 mi north of U.S. Route IA. Blocks under trailers were inundated. Tidal surge or overwash.

$150 \quad$ Lat 42051'47", long 70049'20", Salisbury Beach, Mass., fair ice ring, nail, green flag on pole 39/8 (last pole) off west end of Ilth Street, $0.6 \mathrm{mi}$ south of U.S. Route IA and State Route 86 off North Boulevard, confirmed by transferring marks mentioned by residents. Foundation of westernmost house wetted to a height of 1 to $1.5 \mathrm{ft}$. Water was running westward on IIth Street. Tidal surge or overwash.

$1516.63 \quad$ Lat 42052'I4", long 70049'3I", Seabrook, N.H., fair high-water marks, nail, green flag. Mark is $1.0 \mathrm{ft}$ below flag on pole with meter beside pole 1604, on south side of State Route $86,0.35 \mathrm{mi}$ west of U.S. Route IA., just east of white shack marked "Grapes." Cause of flooding uncertain.

$152 \quad 11.13 \quad$ Lat 42052'l6", long 70049'33", Seabrook, N.H., fair undercut ice ring, nail, green flag on pole 750, nearest to road of two poles on west bank of Blackwater River, about $0.3 \mathrm{ft}$ above "7" in the number 750, on State Route $86,0.35 \mathrm{mi}$ west of U.S. Route IA. Road not flooded. Wave bore. 
Table 1.--Flood data in Maine, New Hampshire, and Massachusetts (Continued)

\begin{tabular}{|c|c|c|}
\hline & $\begin{array}{c}\text { Elevation } \\
(\mathrm{ft})\end{array}$ & Description \\
\hline 153 & 10.65 & $\begin{array}{l}\text { Lat } 42^{\circ} 52^{\prime} \mid 3^{\prime \prime} \text {, long } 70049^{\prime} 43^{\prime \prime} \text {, Seabrook, N.H., good ice ring, nail, } \\
\text { green flag in pole } 742 \text {, on north side of State Route } 86,0.6 \mathrm{mi} \text { west } \\
\text { of U.S. Route IA. Road not flooded. Tidal surge. }\end{array}$ \\
\hline
\end{tabular}

Lat 42052'II", long 70050'24", Seabrook, N.H., good ice ring, nail, green flag on pole 2105, western pole on State Route 86, I.I mi west of U.S. Route IA, north side of road. Road not flooded. Ponded flow on culvert on south side of road. Not flooded from south. Tidal surge.

$1559.47 \quad$ Lat 42053'l4", long 70049'19", Seabrook Beach, N.H., good ice ring, nail, green flag in base of pole with light near shore end of middle pier at Eastman's Wharf. High-water mark near top of fixed portion of pier. Tidal surge.

$156 \quad 9.92 \quad$ Lat 42050'I5", long 70054'22", Salisbury Point, Mass., good wetted lines in snowbank transferred to nail, green flag in willow tree at southeast edge of Merrill Street at downstream edge of culvert. High water topped streambank below culvert, wetting floor of small barn on southwest bank of inlet. Tidal surge.

$157 \quad 6.62 \quad$ Lat 42049'52", long 70051'52", Salisbury, Mass., good ice ring, nail, flag on western support of billboard, west side of U.S. RoutelA (Bridge Road), $0.6 \mathrm{mi}$ south of junction of U.S. Route IA and State Route 1I0. Cause of flooding uncertain.

Lat 42050'09", long 70052'09", Salisbury, Mass., good ice ring, nail, flag in 8-in willow behind 55 Mudnock Street, $0.45 \mathrm{mi}$ from either junction of Mudnock Street or State Route II0. Tidal surge.

Lat 42049'08", long 70051'48", Rings Island, Mass., good ice cakes transferred to nail, flag on pole 88 (east side of Ferry Road) $0.4 \mathrm{mi}$ east on Ferry Road from Bridge Street (U.S. Route IA) at Merrimack River. Not unusual to have ice floes ( $\mathrm{ft}$ to $5 \mathrm{ft}$ thick) on road. This road flooded. Wave bore.

Lat 42049'24", long 70051'03", Rings Island, Mass., good ice ring, nail, flag in 18-in oak tree about $250 \mathrm{ft}$ northeast of south end of Sweet Apple Tree Road along pathway by old sign "You are welcome to use this area on foot." Green flag at high-water mark, orange flag above head level. High-water level just above normal marsh area. Wave bore.

161 10.3 Lat 42050'05", long 70050'I3", Salisbury Beach, Mass., good ice ring, nail, flag in oak tree at southwest edge of Dock Lane opposite pole 19, just northwest of last house on left, $0.6 \mathrm{mi}$ southeast of U.S. Route IA. Tidal surge. 
Table I.--Flood data in Maine, New Hampshire, and Massachusetts (Continued)

\begin{tabular}{|c|c|c|}
\hline $\begin{array}{l}\text { Site } \\
\text { No. }\end{array}$ & $\begin{array}{c}\text { Elevation } \\
(\mathrm{ft})\end{array}$ & Description \\
\hline 162 & 8.36 & $\begin{array}{l}\text { Lat } 42^{\circ} 50^{\prime} 29^{\prime \prime} \text {, long } 70^{\circ} 49^{\prime} 33^{\prime \prime} \text {, Salisbury Beach, Mass., good debris } \\
\text { line transferred to nail, green flag at base of only pitch pine } \\
\text { (between pole } 2 / 85 \text { and } 2 / 86 \text { ) on south side of U.S. Route IA (Beach } \\
\text { Road), } 0.4 \mathrm{mi} \text { west of North Boulevard. Tidal surge. }\end{array}$ \\
\hline
\end{tabular}

1639.36 Lat 42049'59", long 70049'09", Salisbury Beach, Mass., good debris line transferred to stake at southwest corner of "camp office" (small pale-yellow concrete-block building) southwest of toll station at entrance to Salisbury Beach. Mark is essentially top of southwest corner of footing, $0.7 \mathrm{mi}$ south of junction of North Boulevard and Beach Road. Tidal surge.

$164 \quad 10.2$ Lat 42049'18", long 70049'38", Salisbury Beach, Mass., good debris line transferred to flag on southwesternmost tree of clump of willows at west edge of parking lot for boat ramp. At "Block Rocks." Parking lot appeared to be covered by water, but not enough to float away trash barrels. Wave bore.

$165 \quad 10.73 \quad$ Lat 42048'26", long 70051'35", Newburyport, Mass., Merrimack River, good to excellent salt wash line, nail at base of telephone pole $79-11 / 3$ on Water Street next to Coast Guard station behind 51 Craft Center, across from ice house. Photo. Tidal surge.

$166 \quad 10.83 \quad$ Lat 42048'26", long 70051'36", Newburyport, Mass., Merrimack River, good to excellent salt wash line, nail and paint about I ft above bose of telephone pole 2 behind Craft Center directly opposite entrance to 49 Water Street. Photo. Tidal surge.

$167 \quad 10.79$ Lat 42047'59", long 70050'57", Newburyport, Mass., Merrimock River, good to excellent debris line, nail and paint on telephone pole 73 on streamward side of Plum Island Turnpike. Third telephone pole west of Sportsmans Club. Photo. Tidal surge.

$168 \quad 10.14 \quad$ Lat $42^{\circ} 47^{\prime} 54^{\prime \prime}$, Iong 70048'48", Plum Island, Mass., Plum Island River, good salt and seed line, nail and paint in pole 32 at intersection of Plum Island Turnpike and Sunset Drive next to $4 C^{\prime}$ 's Dairy Bar. Photo. Tidal surge.

169 12.37 Lat 42049'00", long 70048'57", Plum Island, Mass., Atlantic Ocean, good salt and debris line, nail and paint on telephone pole! $188-16$ at north end of Plum Island, at southeast corner of Plum Island Fire Station utility shed. Photo. Wave bore or overwash.

$170 \quad 12.60$ Lat 42049'0l", long 70\%48'57", Plum Island, Mass., Atlantic Oceein, good grass and debris line, marked by tags in two places on chain-link fence, about $200 \mathrm{ft}$ east of Plum Island Fire Station. Togs near comfort station. Photo. Wave bore or overwash. 
\begin{tabular}{c} 
Site $\begin{array}{c}\text { Elevation } \\
(\mathrm{ft})\end{array}$ Description \\
\hline
\end{tabular}

$11.10 \quad$ Lat 42046'47", long 70050'02", Pine Island, Mass., Little Pine Island Creek, fair wash line, nail and paint about $5 \mathrm{ft}$ above base of telephone pole on north side of Pine Island Road, 0.5 mi east of U.S. Route IA. Photo. Wave bore.

$172 \quad 10.30 \quad$ Lat $42046 ' 4 I^{\prime \prime}$, long 70050'0I", Pine Island, Mass., Pine Island Creek, fair wash and debris line, high point of rock with painted circle on northeast side, near base of ledge outcrop, $300 \mathrm{ft}$ south of Pine Island Road, 0.5 mi east of U.S. Route IA. Photo. Wave bore.

Lat 42045'02", long 70055'44", Byfield, Mass., Parker River, good to excellent wash line, nail in top of tree stump behind house on right bank of Parker River just downstream from culvert at intersection of Central Street and Orchard Street, $0.8 \mathrm{mi}$ southeast of Interstate Route I-95. Photo. Tidal surge.

Lat 42045'0l", long 70055'42", Byfield, Mass., Parker River, wash line, good to excellent crayon mark and paint ring $2 \mathrm{ft}$ below top of old concrete mill foundation directly across from entrance to house, bankward of site 173. Photo. Tidal surge.

$1759.27 \quad$ Lat 42045'33", long 70053'32", South Byfield, Mass., Parker River, good wash line, crayon mark and paint on right downstream wingwall of U.S. Route I bridge over Parker River. Photo. Tidal surge.

$176 \quad 10.23$ Lat 42045'33", long 70053'29", South Byfield, Mass., Parker River, fair wash line, stake on right bank of Parker River about $150 \mathrm{ft}$ downstream from U.S. Route I near site 175. Photo. Tidal surge.

Lat 42045'07", long 70051'59", Rowley, Mass., Parker River, good to excellent salt line, nail and paint on eighth pole along Boston and Maine Railroad tracks $200 \mathrm{ft}$ south of bridge over Parker River. Photo. Tidal surge.

$178 \quad 9.70 \quad$ Lat $42^{\circ}{ }^{\circ} 5^{\prime} 22^{\prime \prime}$, long 70052'03", Rowley, Mass., Parker River, poor debris and salt line, nail and paint about $3 \mathrm{ft}$ above base of telephone pole on left edge water just upstream of Boston and Maine bridge over Parker River. Photo. Tidal surge.

Lat 42045'19", long 70052'0I", Rowley, Mass., Parker River, good to excellent debris line, paint mark on rock with crayon in center, at right downstream edge of water at Boston and Maine bridge over Parker River. Photo. Tidal surge.

7.79 Lat 42046'26", long 70052'02", Newburyport, Mass., Little River, fair salt wash line, nail and paint on telephone pole 53PB just west of intersection of Hay Street and Newman Road. Photo. Tidal surge. 
Table I.--Flood data in Maine, New Hampshire, and Massachusetts (Continued)

\begin{tabular}{ccl}
\hline $\begin{array}{c}\text { Site } \\
\text { No. }\end{array}$ & $\begin{array}{c}\text { Elevation } \\
(\mathrm{ft})\end{array}$ & \multicolumn{1}{c}{ Description } \\
\hline 181 & 8.81 & $\begin{array}{l}\text { Lat 42046'27", long 70051'58", Newburyport, Mass., Little River, fair } \\
\text { salt wash line, nail and paint about } 3 \mathrm{ft} \text { above base of telephone }\end{array}$ \\
& & $\begin{array}{l}\text { pole } 51 \text { on right upstream bank of bridge over Little River at } \\
\text { intersection of Hay Street and Newman Road. Photo. Tidal surge, }\end{array}$ \\
& $\begin{array}{l}\text { High water went at least upstream to railroad tracks. Inconsistency } \\
\text { between elevations of sites } 180 \text { and } 181 \text { uncertain. Possible, but not } \\
\text { probable, that marks are from high surface runoff about January 27. }\end{array}$
\end{tabular}

$182 \quad 6.90 \quad$ Lat 42045'46", long 70050'53", Newbury Old Town, Mass., Parker River, excellent salt wash line, crayon line and painted circles $0.6 \mathrm{ft}$ above granite blocks at left downstream edge of bridge wingwall, on U.S. Route IA bridge over Parker River. Photo. Reason for low elevation uncertain.

$183 \quad 10.13$ Lat 42043'I", long 7005I'31", Rowley, Mass., Rowley River, good to fair wash line, nail and paint on right upstream wingwall on vertical plank, at Boston and Maine Railroad bridge over Rowley River at Rowley. Photo. Tidal surge.

$184 \quad 10.77$ Lat 42043'20", long 7005/'29", Rowley, Mass., Rowley River, good to fair wash line, paint line on face of left downstream end wingwall of Boston and Maine Railroad bridge over Rowley River. Photo. Wave bore.

$185 \quad 10.56$ Lat 42043'30", long 7005I'23", Rowley, Mass., Rowley River, discoloration on northerly cement block wall of Alexander's home at end of Batcheldors Landing at Rowley. High-water-mark description and elevation furnished by the Massachusetts Department of Public Works. Two photos. Probably wave bore.

$1869.66 \quad$ Lat 42044'15", long 7005l'33", Rowley, Mass., West Creek, fair debris line, stake just over bank of road off U.S. Route IA, $0.2 \mathrm{mi}$ northeast of Boston and Maine Railroad tracks, directly opposite entrance to Savory Auto Parts. Photo. Tidal surge.

$187 \quad 10.15 \quad$ Lat 42041'53", long 70050'16", Ipswich, Mass., Eagle Hill River, fair wash line, nail and paint ring at base of tree off Greens Point Road. Take right at telephone pole 14 toward Bowen's house, mark half way down road to right at edge of marsh. Photo. Tidal surge.

$188 \quad 10.90$

Lat 42042'00", long 70048'02", Ipswich, Mass., Eagle Hill River, poor salt and wash line, nail and paint mark about $3 \mathrm{ft}$ above base of telephone pole 80 on north side of Jaffreys Neck Road about I.Imi northeast of Ipswich. Photo. Wave bore. Water over road in this area. 
Table 1.--Flood data in Maine, New Hampshire, and Massachusetts (Continued)

Site Elevation $(\mathrm{ft})$

Description

No.

$189 \quad 9.58$

Lat 4204l'58", long 70048'06", Ipswich, Mass., Neck Creek, poor salt and wash line, nail and paint mark about $2.5 \mathrm{ft}$ above base of telephone pole 78 on south side of Jaffreys Neck Road, about $1.1 \mathrm{mi}$ northeast of Ipswich. Photo. Wave bore.

$190 \quad 5.9$

Lat 42041'02", long 70049'4l", Ipswich, Mass., Ipswich River, good to fair wash line, nail and paint ring on telephone pole at center of parking lot off East Street at Ipswich boat landing, directly across from pump house and to the river side of concrete retaining wall. Photo. Tidal surge. Reason for low elevation uncertain.

191 7.ll Lat 42041'03", long 70049'39", Ipswich, Mass., Ipswich River, poor wash line, high point of rock marked by paint ring on block wall at Town of Ipswich boat landing, next to launching ramp just to left of drain pipe. Photo. Tidal surge.

$192 \quad 13.08$

Lat 42041'54", long 70047'37", Ipswich, Mass., Ipswich River side of Ipswich Bay, good to excellent debris line, stake at corner of Little Neck Road where it turns to go out to Little Neck. Photo. Wave bore.

Lat 42041'49", long 70047'32", Ipswich, Mass., Ipswich River side of Ipswich Bay, good to excellent debris line, paint mark about $1.5 \mathrm{ft}$ above ground on right side of right stone gateway to Little Neck. Photo. Wave bore.

Lat 42039'17", long 70048'28", Ipswich, Mass., Castle Neck River, good debris line, stake behind Essex Lobster Co. on left upstream side of culvert passing under side road off State Route 133, about $800 \mathrm{ft}$ southeast of Northgate Road. Photo. Tidal surge. Culvert restriction.

$195 \quad 10.98$ Lat 42039'I6", long 70048'25", Ipswich, Mass., Castle Neck River, good debris line, stake behind Essex Lobster Co. on right downstream side of culvert. See site 194. Photo. Tidal surge.

$196 \quad 10.22$ Lat 42040'32", long 70047'I"', Ipswich, Mass., Castle Neck River, good debris in 5-in-diameter bushes, nail in 5-in bush and flag high in bush at edge of marsh area on Castle Hill River side of Argilla Road about $300 \mathrm{ft}$ west of site 198. Photo. Tidal surge.

$197 \quad 10.60$ Lat 42040'34", long 70047'l0", Ipswich, Mass., Fox Creek, good wash line, crayon line with paint ring on concrete wall at bridge on north side of Argilla Road, $1.4 \mathrm{mi}$ east of intersection of Argilla Road and Northgate Road. Photo. Tidal surge partially affected by bore. 
Table 1.--Flood data in Maine, New Hampshire, and Massachusetts (Continued)

\begin{tabular}{lll}
\hline $\begin{array}{l}\text { Site } \\
\text { No. }\end{array}$ & $\begin{array}{c}\text { Elevation } \\
(\mathrm{ft})\end{array}$ & Description \\
\hline 198 & 10.25 & $\begin{array}{l}\text { Lat 42040'33", long 70047'08", Ipswich, Mass., Castle Neck River, } \\
\text { good debris line, nail and paint ring about } 2 \mathrm{ft} \text { above base of } \\
\text { telephone pole } 150 \text { about } 100 \mathrm{ft} \text { west of bridge over Fox Creek on } \\
\end{array}$ \\
& Argilla Road. Photo. Tidal surge.
\end{tabular}

$199 \quad 10.96 \quad$ Lat 42037'5l", long 70046'36", Essex, Mass., Essex River, excellent oil line, crayon mark $2 \mathrm{ft}$ above bottom of cinder block on outside of left rear wall of Texaco station upstream of State Routel 33 between Essex and South Essex. Photo. Tidal surge.

$200 \quad 12.03 \quad$ Lat 42037'53", long 70046'37", Essex, Mass., Essex River, good to fair wash line, nail and paint ring about $4 \mathrm{ft}$ above base of telephone pole 276/294 on downstream side of Main Street (State Routel33) next to marina. Photo. Wave bore and wind effects.

$2018.58 \quad$ Lat 42038'05", long 70044'08", Gloucester, Mass., Walker Creek, fair debris line, stake on west side of Summer Street about $300 \mathrm{ft}$ from intersection with Concord Street. Photo. Tidal bore.

$202 \quad 9.20 \quad$ Lat 42038'06", long 70044'09", Gloucester, Mass., Walker Creek, foir debris line, stake on west side of Summer Street about $150 \mathrm{ft}$ from intersection with Concord Street. Tidal bore.

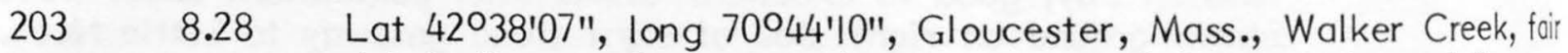
debris line, stake at southwest corner of intersection of Summer Street and Concord Street. Two photos. Tidal surge.

204 8.62 Lat 42038'07", long 70044'II", Gloucester, Mass., Walker Creek, fair wash line, paint ring on high point of granite block about $10 \mathrm{ft}$ below top of bridge wall on right upstream side bridge over Walker Creek on Concord Street. Photo. Tidal surge.

205 7.23 Lat 42036'40", long 70040'48", Gloucester, Mass., Annisquam River at Blynman Canal, good to fair wash line, center of paint mark on rock wall about $30 \mathrm{ft}$ northwest of point where culvert passes under State Route 133, about $0.25 \mathrm{mi}$ from intersection of State Routes 133 and 127. Photo. Mark not as good as site 206. Tidal surge.

$2068.95 \quad$ Lat 42036'42", long 70040'5l", Gloucester, Mass., Annisquam River at Blynman Canal, good to excellent debris line, painted high point of rock off State Route 133 on wall between Mobil station and motel. Photo. Mark considered more reliable than site 205 . Tidal surge.

207 II.II Lat 42037'35", long 70041'59", Gloucester, Mass., Jones River, good to fair wash line transferred from bank to nail and paint ring at base of telephone pole 13 on Causeway Street next to Freddie's Lobster Land off exit 12 of State Route 128. Photo. Possibly wave bore. 
17.03 Lat 42039'43", long 70037'29", Rockport, Mass., Sandy Bay, good wash line, nail and paint ring about $0.8 \mathrm{ft}$ above base of telephone pole 16 on bankward side of Back Beach, at edge of parking area. Photo. Wave bore.

Lat 42037'54", long 70037'l7", Gloucester, Mass., Saratoga Creek behind Long Beach, good wash line, high point of painted circle on ledge along State Route I27A about $50 \mathrm{ft}$ west of point where Saratoga Creek passes under State Route I27A. Tidal surge.

9.40 Lat 42037'54", long 70037'07", Gloucester, Mass., Saratoga Creek behind Long Beach, good wash line, paint mark at high point of rock about $300 \mathrm{ft}$ east of site 209 just off State Route I27A. Photo. Tidal surge.

9.18 Lat 42037'57", long 70036'59", Gloucester, Mass., Saratoga Creek behind Long Beach, good debris line, nail and paint near base of 10 -in-diameter tree about $300 \mathrm{ft}$ east of site 210 along Saratoga Creek. Photo. Tidal surge.

11.74 Lat 42037'59", long 70036'54", Gloucester, Mass., Saratoga Creek behind Long Beach, fair wash line, paint circle at high point on ledge outcrop $300 \mathrm{ft}$ east of site 211 along Saratoga Creek. Photo. Tidal surge. NOTE: Higher elevation than sites 209-2II may indicate that mark was affected by splash.

11.03 Lat 42037'17", long 70037'55", Gloucester, Mass., Good Harbor Beach, good wash line, nail and paint ring about $3 \mathrm{ft}$ above base of third telephone pole (7556) on left from entrance to Good Harbor Beach off State Route I27A. Photo. Tidal surge possibly combined with bore.

8.04 Lat 42037'23", long 70038'03", Gloucester, Mass., Good Harbor Beach, good wash and debris line in sheltered area, nail and paint ring about I ft above base of telephone pole 7592 just across marsh on State Route 127 from Good Harbor Beach where creek passes under State Route I27A. Photo. Tidal surge.

6.84 Lat 42034'27", long 70046'23", Manchester, Mass., Manchester Harbor, excellent wash line, crayon and paint ring $2.3 \mathrm{ft}$ above footing of retaining wall at inner harbor next to parking area of American Legion Post. Photo. Tidal surge. Reason for low elevation uncertain.

9.49 Lat 42034'20", long 70046'23", Manchester, Mass., Manchester Harbor, good debris line, paint ring at high point of rock on inland side of railroad tracks between inner and outer harbor. Photo. Tidal surge. 
Table I.-Flood data in Maine, New Hampshire, and Massachusetts (Continued)

\begin{tabular}{lll}
\hline $\begin{array}{c}\text { Site } \\
\text { No. }\end{array}$ & $\begin{array}{c}\text { Elevation } \\
(\mathrm{ft})\end{array}$ & \multicolumn{1}{c}{ Description } \\
\hline 217 & 9.51 & $\begin{array}{l}\text { Lat } 42^{\circ} 34^{\prime 22} \text { ", long 70046'24", Manchester, Mass., Manchester } \\
\text { Harbor, good debris and wash line, nail and paint ring Ift above bose } \\
\text { of telephone pole near railroad tracks and bridge connecting the } \\
\text { inner and outer harbors. Photo. Tidal surge. }\end{array}$
\end{tabular}

$218 \quad 7.52$ Lat 42034'09", long 70047'40", Manchester, Mass., Chubb Creek, good debris line, paint ring at high point of rock on left downstream bank where Chubb Creek passes under State Route 127. Photo. Tidal surge.

$219 \quad 7.10 \quad$ Lat 42034'08", long 70047'36", Manchester, Mass., Chubb Creek, fair to poor debris line, paint mark on concrete block on easterly edge of marsh, on left downstream side of Chubb Creek at State Route 127. Photo. Tidal surge.

220 8.71 Lat 42034'04", long 70047'36", Manchester, Mass., Chubb Creek, good to fair debris line, stake at easterly edge of Chubb Creek marsh below State Route 127, about $100 \mathrm{ft}$ seaward of site 219. Photo. Tidal surge.

$221 \quad 7.22 \quad$ Lat 42034'04", long 70055'42", Danvers, Mass., Porter River, fair seed line in snow and along headwall, drift line $0.55 \mathrm{ft}$ above corner of concrete block attached to right downstream headwall of Porter River culvert at intersection of Poplar, Elliot, and Conant Streets. Photo. Tidal surge.

$2229.10 \quad$ Lat 42033'26", long 70055'24", Danvers, Mass., Porter River, good silt and debris line, nail and flag at base of telephone pole 38 on Liberty Street at downstream side of Porter River culvert. Photo. Tidal surge.

$223 \quad 8.70 \quad$ Lat 42033'36", long 70055'03", Danvers, Mass., Porter River inlet, good to fair drift line on rocks and bank, mark $0.85 \mathrm{ft}$ below nail in streamward side of top landing near Danvers Yacht Club public landing. Photo. Tidal surge.

$224 \quad 7.46 \quad$ Lat 42032'49", long 70056'/4", Danvers, Mass., Waters River, good salt and debris line, nail and flag in slanted piling on upstream side of southbound lane of State Route 128 over Waters River near Catch Penny Chalet Motor Lodge. Photo. Tidal surge.

$2259.99 \quad$ Lat 42033'17", long 70053'l'", Beverly, Mass., Bass River, excellent drift and silt line, $0.42 \mathrm{ft}$ above clubhouse back door sill of Bass Harbor Yacht Club on United Shoe Machinery property. Tidal surge. 
Table 1.-Flood data in Maine, New Hampshire, and Massachusetts (Continued)

9.09 Lat 42031'29", long 70053'58", Salem, Mass., North River, good drift line in snow, nail, paint, and flag in top of wooden cover over seaward side of concrete box culvert next to HMA car wash, on State Route 107 near railroad tracks. Photo. Tidal surge.

Lat 42030'43", long 70053'17", Salem, Mass., Salem Harbor, good drift and debris line along shrubs and chain link fence $1.35 \mathrm{ft}$ above sidewalk at corner of Lafayette Place and Lafayette Place extension at Palmer Cove. Photo. Probably tidal surge; mark at higher elevation than seawall.

Lat 42029'32", long 70050'47", Marblehead Neck, Mass., Marblehead Harbor, fair drift mark $0.65 \mathrm{ft}$ above base of U.S. Postal Service mail box at corner of Causeway Street and Harbor Avenue. Waves driven over seawall and road.

Lat 42028'44", long 70052'5l", Marblehead-Swampscott, Mass., town line, Massachusetts Bay at Phillips Beach, good debris line in chain link fence $0.95 \mathrm{ft}$ above stone wall at "Entering Marblehead" sign. Photo. Wave bore.

Lat 42028'22", long 70053'll", Swampscott, Mass., Massachusetts Bay at Phillips Beach, excellent drift and debris line marked by flag, on chain link fence directly opposite telephone pole 143/1 on Shepard Avenue at Phillips Beach. Photo. Tidal surge; site beyond limit of wave bore.

Lat 42027'5l", long 70054'20", Swampscott, Mass., Massachusetts Bay at Whales Beach, good fine-drift line in snow and on iron fence $1.85 \mathrm{ft}$ above granite curb at 152 Puritan Road at Whales Beach. Photo. Wave bore.

Lat 42027'28", long 70056'l7", Lynn, Mass., Lynn Harbor, excellent wash line, pencil mark placed during flood, about $2.5 \mathrm{ft}$ above base of aluminum door molding of Richdale Superette at Lynn rotary. Photo. High-water mark verified by damage inside store. Tidal surge.

Lat 42026'l3", long 70056'l0", Little Nahant, Mass., Nahant Bay, very good debris and wash line at Babcon Package Store on Nahant Road. Photo. Owner's statement to survey crew that no water reached this building is not supported by the evidence. Waves overtopped seawall.

14.75 Lat $42^{\circ} 25^{\prime} 37^{\prime \prime}$, long 70055'5l", Nahant, Mass., Nahant Bay, fair debris line approximately $1.5 \mathrm{ft}$ below top of back side of concrete wall to left of door of house at III Flash Road. Photo. Tidal surge. 
Table I.-Flood data in Maine, New Hampshire, and Massachusetts (Continued)

\begin{tabular}{|c|c|c|}
\hline $\begin{array}{l}\text { Site } \\
\text { No. }\end{array}$ & $\begin{array}{c}\text { Elevation } \\
(\mathrm{ft})\end{array}$ & Description \\
\hline 235 & 18.28 & $\begin{array}{l}\text { Lat } 42025^{\prime} 15^{\prime \prime} \text {, long } 70^{\circ} 55^{\prime} 06^{\prime \prime} \text {, Nahant, Mass., Nahant Harbor, good } \\
\text { wash and debris line } 1.5 \mathrm{ft} \text { above base of tree in harbor park areo } \\
\text { near Nahant Dory Club and boatyard. Photo. Wave overwash. }\end{array}$ \\
\hline 236 & 15.12 & $\begin{array}{l}\text { Lat } 42^{\circ} 25^{\prime} 07 " \text {, long } 70^{\circ} 55^{\prime} / 2^{\prime \prime} \text {, Nahant, Mass., Nahant Harbor, good } \\
\text { fine-debris line at top of third mortar joint at north corner of } \\
\text { foundation of } 76 \text { Willow Road at junction of Emerald Street, Ocean } \\
\text { Street, and Willow Road. Photo. Tidal surge. }\end{array}$ \\
\hline 237 & 22.04 & $\begin{array}{l}\text { Lat } 42^{\circ} 25^{\prime} 07 " \text { ", long } 700566^{\prime} 00^{\prime} \text {, Nahant, Mass., Broad Sound at Lewis } \\
\text { Cove, very good salt and debris line at bottom of twelfth brick up } \\
\text { from ground level near front door of } 132 \text { Base Point Road at corner } \\
\text { of Spinney and Bass Point Roads. Photo. High-water mark elevation } \\
\text { verified by damage inside home. Waves overtopped seawall; water } \\
\text { entrapped. }\end{array}$ \\
\hline
\end{tabular}

$238 \quad 18.33 \quad$ Lat 42025'39", long 70056'09", Nahant, Mass., Broad Sound at Block Rock Beach, fair debris line about $1.0 \mathrm{ft}$ above base of hydrant at 118 Castle Road. Limit of flooding on Castle Road. Photo. Tidal surge; possibly affected by waves overtopping seawall.

$239 \quad 15.20 \quad$ Lat $42^{\circ} 25^{\prime} 17^{\prime \prime}$, long 70056'05", Nahant, Mass., Broad Sound easterly of Coast Guard Station, good wash and debris line 2.I ft below top of left corner (from front) of foundation at 12 Castle Road. Photo, Tidal surge; possibly affected by waves over seawall.

$2407.2 \quad$ Lat 42025'26", long 7/०00'09", Revere, Mass., Pines River, Diamond Creek marsh, fair debris line, top of nut painted and flagged on steel base of second billboard on State Route 107 north from Brown Circle. Photo. Tidal surge.

$241 \quad 7.17$ Lat 42026'26", long 70057'54", Revere, Mass., Point of Pines, very good wash and drift line in snow at base of hydrant across from 35 Fowler Avenue near Point of Pines Yacht Club. Photo. Waves overtopped seawall, water entrapped.

$242 \quad 14.58$ Lat $42^{\circ} 25^{\prime} 43^{\prime \prime}$, long 70058'47", Revere, Mass., Broad Sound at Revere Beach, good drift and debris line on lawn $0.2 \mathrm{ft}$ above grass at base of shrub at 624 Revere Beach Parkway. Photo. Waves over seawall.

$243 \quad 23.55$

Lat 42०25'07", long 70059'23", Revere, Mass., Broad Sound at Revere Beach, fair wash and debris line about even with base of hydrant on right side of Revere Beach rotary at junction of Revere Beach Parkway and State Route 60. Photo. Mark was at limit of wind-driven ocean water which caused flooding of adjacent low areas. Waves over seawall and across road. 
Table 1.--Flood data in Maine, New Hampshire, and Massachusetts (Continued)

\begin{tabular}{|c|c|c|}
\hline & $\begin{array}{c}\text { Elevation } \\
(\mathrm{ft})\end{array}$ & Description \\
\hline & 13.00 & $\begin{array}{l}\text { Lat } 42^{\circ} 24^{\prime} 04^{\prime \prime} \text {, long } 70059 \text { 'I", Revere, Mass., Beachmont section, } \\
\text { Broad Sound, good debris line marked by sign placed on house at } \\
\text { corner of Foam Avenue and Broad Sound Avenue reading "Mean high } \\
\text { tide Feb.7, 1978." Sign not there at time of survey, mark location } \\
\text { determined from photo. Waves over seawall. }\end{array}$ \\
\hline
\end{tabular}

$245 \quad 11.44$

Lat 42023'38", long 70058'57", Revere, Mass., Beachmont section, Broad Sound, behind seawall, good wave line on blue house right next to Metropolitan District Commission building92 on Broad Sound Avenue. Waves over seawall.

$246 \quad 11.86$ Lat 42023'l4", long 70058'15", Revere, Mass., Beachmont section, Broad Sound, fair wash line $0.8 \mathrm{ft}$ above base of corner post of stockade fence near 83 Leverett Avenue. A higher line on picket fence may indicate some surging. Photo. Waves over seawall.

$247 \quad 14.50 \quad$ Lat 42023'23", long 70058'49", Revere, Mass., Beachmont section, Short Beach, good wash line $1.25 \mathrm{ft}$ up on chimney bricks of |2| Upland Road. Photo. Waves over seawall.

$248 \quad$ 12.45 Lat 42022'4l", long 70058'22", Winthrop, Mass., Winthrop Beach, good wash line on seventh clapboard from ground at 65 Beach Street, halfway between seventh and eighth clapboard. Photo. Waves over seawall.

$249 \quad 7.0$ Lat 42022'l6", long 70058'I2", Winthrop, Mass., Cottage Hill, good drift line $1.8 \mathrm{ft}$ above base of chain link fence across street from Hadassah Way and Temple Tifreth Israel. Photo. Waves over seawall.

250 12.67 Lat 42021'33", long 70058'16", Winthrop, Mass., Point Shirley, good to fair debris line $1.8 \mathrm{ft}$ above sidewalk on chain link fence at 965 Bayview on corner. Photo. Waves over seawall.

25111.04 Lat 42021'26", long 70058'l6", Point Shirley, Mass., Boston Harbor, right side of garage, brick ranch, at 25 Maryland Avenue. High-water-mark description and elevation furnished by the Massachusetts Department of Public Works. Cause of flooding not determined.

252 Lat 42021'27", long 70058'20", Point Shirley, Mass., Boston Harbor, foundation and mail box at 80 Otis Street. High-water-mark description and elevation furnished by the Massachusetts Department of Public Works. Cause of flooding not determined. 
Table 1.--Flood data in Maine, New Hampshire, and Massachusetts (Continued)

\begin{tabular}{|c|c|c|}
\hline $\begin{array}{l}\text { Site } \\
\text { No. }\end{array}$ & $\begin{array}{c}\text { Elevation } \\
(\mathrm{ft})\end{array}$ & Description \\
\hline 253 & 11.09 & $\begin{array}{l}\text { Lat } 42^{\circ} 2 I^{\prime} 27 " \text { ", long } 70058 ' 20^{\prime \prime} \text { Point Shirley, Mass., Boston Harbor, } \\
\text { mail box near driveway of } 82 \text { Otis Street. High-water-mark } \\
\text { description and elevation furnished by the Massachusetts } \\
\text { Department of Public Works. Cause of flooding not determined. }\end{array}$ \\
\hline 254 & 10.38 & $\begin{array}{l}\text { Lat 42022'06", long 70058'20", Cottage Hill, Mass., Crystal Cove, } \\
\text { debris line at lower locker deck of Winthrop Yacht Club, } 649 \text { Shirley } \\
\text { Street. High-water-mark description and elevation furnished by the } \\
\text { Massachusetts Department of Public Works. Cause of flooding not } \\
\text { determined. }\end{array}$ \\
\hline $254 \mathrm{~A}$ & 11.0 & $\begin{array}{l}\text { Lat } 42^{\circ} 23^{\prime} 40^{\prime \prime} \text {, long } 71^{\circ} 04^{\prime} 30^{\prime \prime} \text {, Medford, Mass., tide gage at Amelio } \\
\text { Earhart Dam. Record furnished by the Metropolitan District } \\
\text { Commission. Tidal surge. }\end{array}$ \\
\hline 255 & 9.62 & $\begin{array}{l}\text { Lat } 42^{\circ} 24^{\prime} \mid l " \text { ", long } 71^{\circ} 01 ' 38 " \text {, Chelsea, Mass., Mill Creek, fair debris } \\
\text { line on wall and snow, flagged } 0.57 \mathrm{ft} \text { above } 9 \text { - } \mathrm{ft} \text { mark on staff gage } \\
\text { (steel pipe set in concrete) on upstream headwall of Mill Creek on } \\
\text { Broadway Avenue. Photo. Tidal surge, constricted flow. }\end{array}$ \\
\hline 256 & 10.3 & $\begin{array}{l}\text { Lat } 42^{\circ} 23^{\prime} 09^{\prime \prime} \text { long } 7 I^{\circ} 0 I^{\prime} 5 I^{\prime \prime} \text {, Chelsea, Mass., Chelsea River, good to } \\
\text { fair drift and debris line on pier, nail in pier of Metropolitan District } \\
\text { Commission Sewerage Division maintenance yard on Chelsea Street. } \\
\text { Photo. Tidal surge, constricted flow. }\end{array}$ \\
\hline
\end{tabular}

256A 10.6 Lat 42022'07", long 7/003'43", Boston, Mass., tide gage at new Charles River Dam. Record furnished by the U.S. Army Corps of Engineers. Tidal surge.

$256 \mathrm{~B} 10.4 \quad$ Lat $42^{\circ} 2 \mathrm{I}^{\prime} 17^{\prime \prime}$, long 7/003'04", Boston, Mass., National Ocean Survey tide gage at Commonwealth Pier. Record furnished by the National Ocean Survey. Tidal surge.

$2578.44 \quad$ Lat 42015'42", long 71002'5l", Quincy, Mass., Gulliger Creek, good to fair debris line in tree $15 \mathrm{ft}$ below West Squantum Street culvert at the corner of Christopher Drive. Tidal surge.

$258 \quad 10.28 \quad$ Lat 42016'40", long 7/०03'/8", Quincy, Mass., Neponset River, flagged excellent drift line in corner of chain link fence of Cedar Grove Cemetery about $210 \mathrm{ft}$ upstream of Granite Street drawbridge. Photo. Tidal surge.

$259 \quad 10.30$ Lat 42016'28", long 7/001'5l", Quincy, Mass., Neponset River tributary, flagged fair drift line on bank and on top of 4-in PVC groy plastic pipe between WMEX radio towers and new high-rise apartment, about $100 \mathrm{ft}$ from West Squantum Street. Photo. Tidol surge. 
Table 1.-Flood data in Maine, New Hampshire, and Massachusetts (Continued)

\begin{tabular}{|c|c|c|}
\hline & $\begin{array}{c}\text { Elevation } \\
(\mathrm{ft})\end{array}$ & Description \\
\hline & 10.4 & $\begin{array}{l}\text { Lat } 42017{ }^{\circ} 28 " \text {, long } 71001 ' 21 " \text {, Squantum, Mass., Quincy Bay, very good } \\
\text { debris line } 0.9 \mathrm{ft} \text { below top rail of chain link fence on East Squantum } \\
\text { Street across road from telephone pole } 68 \text { MECO near Myles } \\
\text { Standish School. Photo. Tidal surge. }\end{array}$ \\
\hline
\end{tabular}

261 12.94 Lat 42017'36", long 71000'28", Squantum, Mass., Quincy Bay, good debris line, arrow scratched in stone wall at boat-launching ramp at southern end of Bellevue Road. Photo. Wave bore.

$2629.00 \quad$ Lat 42015'52", long 70059'06", Quincy, Mass., Quincy Bay, Merrymont section of Adams Shore, fair drift line from several locations determined to be $0.4 \mathrm{ft}$ above small sewer cover next to fire hydrant, on ocean side. Photo. Waves over seawall.

$263 \quad 10.27 \quad$ Lat 42015'43", long 70058'29", Quincy, Mass., Quincy Bay, very good debris line on chain link fence determined to be $2.15 \mathrm{ft}$ above center of road at 99 Post Island Road. Photo. Tidal surge over seawall from north and from Rock Island Cove to the east. Heavy concentration of ice cakes in this area.

$264 \quad 11.91 \quad$ Lat 42015'55", long 70058'14", Quincy, Mass., Quincy Bay, very good debris line on chicken wire, post-and-rail fence $2.55 \mathrm{ft}$ above center of road at II Babcock Street. Tidal surge and waves over seawall. Possible effect from Rock Island Cove to southeast.

$265 \quad 11.47 \quad$ Lat 42016'I5", long 70057'24", Quincy, Mass., Houghs Neck, Quincy Bay, good debris line on chain link fence transferred to nail in telephone pole NEES T-74 SPC 4-35 on Bayswater Road end of street next to Gambles Landing. Photo. Wave bore.

$266 \quad 9.9 \quad$ Lat $42^{\circ}{ }^{\prime} 5^{\prime} 08^{\prime \prime}$, long 70059'23", Quincy, Mass., Town River, fair debris line transferred to paint mark on right downstream side of State Route 3A bridge over Town River near Quincy Lumber Co. Photo. Tidal surge.

$267 \quad 7.05$ Lat 42013'20", long 70058'27", Weymouth, Mass., Weymouth Fore River, paint mark (elev 13.05 ft) $6.0 \mathrm{ft}$ above good ice line, on right downstream side of Shaw Street bridge over Weymouth Fore River. Photo. Tidal surge.

$268 \quad 7.56 \quad$ Lat 42013'27", long 70057'55", Weymouth, Mass., Weymouth Fore River, excellent debris line, paint mark $1.6 \mathrm{ft}$ below top of concrete base of road sign along shore opposite Webb Park about I,200 ft downstream from Quincy Avenue bridge over Weymouth Fore River. Photo. Tidal surge. 
Table 1.-Flood data in Maine, New Hampshire, and Massachusetts (Continued)

\begin{tabular}{ccl}
\hline $\begin{array}{c}\text { Site } \\
\text { No. }\end{array}$ & $\begin{array}{c}\text { Elevation } \\
(\mathrm{ft})\end{array}$ & \multicolumn{1}{c}{ Description } \\
\hline 269 & 6.85 & $\begin{array}{l}\text { Lat 42014'17", long 70056'59", Weymouth, Mass., Weymouth Fore } \\
\text { River tributary, excellent debris line, paint mark on left downstream } \\
\text { side culvert headwall on Pearl Street over tributary to Mill Cove at } \\
\text { Johnson School. Photo. Tidal surge. }\end{array}$
\end{tabular}

$270 \quad$ 13.3 Lat 42015'24", long 70056'07", Weymouth, Mass., Rose Cliff, Hingham Bay, good debris line $3.6 \mathrm{ft}$ above center of road at end of 7 Caldwell Street driveway beside fence pipe. Photo. Wave bore.

$271 \quad$ II.7I. Lat 42015'42", long 70053'39", Hull, Mass., Hingham Harbor at Crow Point, very good wash line $2.05 \mathrm{ft}$ below top spindle of fire hydrant in front of Hingham Yacht Club at Marion Street sign. Photo, Waves over seawall.

$2728.92 \quad$ Lat 42015'08", long 70051'33", Hingham, Mass., Weir River, good drift line, nail in base of telephone pole at intersection of Spring Alley and Rockland Street. Photo. Tidal surge.

$273 \quad$ Lat 42016'29", long 70051'51", Hull, Mass., Sagamore Hill, Weir River tidal flat, good wash and debris line on bank, l.I ft above center of headwall on harbor side of corner of A Street and Water Street. Photo. Tidal surge.

$274 \quad 11.49 \quad$ Lat 42017'28", long 70053'00", Hull, Mass., Waveland, Hull Bay, very good debris line marked by nail at ground level $1.65 \mathrm{ft}$ below mark o 23 A Street. Photo. Waves over seawall.

275 10.54 Lat 42018'0I", long 70053'll", Hull, Mass., Bayside, Hull Bay, very good debris line on chain link fence, hub at ground level $3.05 \mathrm{ft}$ below mark at corner of fence on $Q$ Street. Waves over seawall.

$276 \quad$ II.40 Lat 42018'07", long 70054'20", Hull, Mass., Nantasket Roads, foir wash line on side of house at 14 Arthur Street, $4.6 \mathrm{ft}$ above ground level. Photo. Waves over seawall.

277 II.23 Lat 42018'19", long 70054'52", Hull, Mass., Pemberton Seawall, Nantasket Roads, very good debris line $1.25 \mathrm{ft}$ above middle horizontal bar of baseball backstop at James D. Sullivan playground across street from Joe's Nautical Bar. Photo. Waves over seawall.

278 13.89 Lat 42010'24", long 70054'09", Hull, Mass., Stony Beach, Nantasket Roads, very good debris and wash line, nail $5.8 \mathrm{ft}$ above base of 36 -in tree at 1147 Nantasket Avenue, behind house near corral and stable. Two photos. Wave bore. 
Table 1.-Flood data in Maine, New Hampshire, and Massachusetts (Continued)

\begin{tabular}{|c|c|c|}
\hline & $\begin{array}{c}\text { Elevation } \\
(\mathrm{ft})\end{array}$ & Description \\
\hline 279 & 13.36 & $\begin{array}{l}\text { Lat } 42^{\circ}\left(8^{\prime} 33^{\prime \prime} \text {, long } 70^{\circ} 53^{\prime} 25^{\prime \prime} \text {, Hull, Mass., Allerton Hill, Nantasket }\right. \\
\text { Roads, fair to poor debris line on fence and house, pencil line } 0.35 \mathrm{ft} \\
\text { up on second wooden step of } 9 \text { Point Allerton Avenue at intersection } \\
\text { with Glover Avenue. Waves over seawall. }\end{array}$ \\
\hline
\end{tabular}

$280 \quad 10.05$ Lat 42018'l8", long 70053'04", Hull, Mass., Nantasket Beach, Massachusetts Bay, good debris line, nail $1.45 \mathrm{ft}$ above base of telephone pole $155 / 4$ at corner of $X$ and $Y$ Streets. Photo. Flooding probably due to tidal surge from west.

$281 \quad 11.34$ Lat 42018'06", long 70052'58", Hull, Mass., Nantasket Beach, Massachusetts Bay, excellent wash line marked by nail $0.9 \mathrm{ft}$ above outside corner of porch at 6 Erwin Street. Elevation confirmed by debr is line on nearby chain link fence. Photo.

282 13.64 Lat 42016'46", long 70052'06", Hull, Mass., White Head, Nantasket Beach, Massachusetts Bay, very good wash line $0.7 \mathrm{ft}$ below shingle at left corner of foundation of 25 Samoset Avenue, near electric light meter. Photo. Waves over seawall.

283 10.91 Lat 42016'00", long 70050'30", Hull, Mass., Straights Pond, Massachusetts Bay, very good debris line $1.65 \mathrm{ft}$ above base of corner post of chain link fence enclosing playground on Atlantic Avenue, and $\mathrm{l} . \mathrm{I} \mathrm{ft}$ above nail in center of road. Photo. Waves over seawall.

Lat 42015'35", long 70048'41", Hingham, Mass., Pleasant Beach on Massachusetts Bay, excellent wash and debris line, stake on embankment at corner of Atlantic Avenue and Jerusalem Road, also crayon mark on granite block. Photo. Wave bore.

$285 \quad 10.89$

Lat 42015'26", long 70048'49", Cohasset, Mass., Little Harbor, good debris line, nail $4.4 \mathrm{ft}$ above base of telephone pole BECO 28 NET \&TCO on Jerusalem Road within Bow Street loop. Photo. Tidal surge.

$286 \quad 10.48$ Lat 42014'52", long 70048'37", Cohasset, Mass., Little Harbor, excellent debris line, paint, nail, tag on tree at road junction at southern end of Central Cemetery. Photo. Tidal surge.

287 10.28 Lat 42014'58", long 70047'52", Cohasset, Mass., Little Harbor, excellent debris line, paint, nail, and tag on tree near telephone pole 24 on Beach Street. Photo. Tidal surge.

$288 \quad 11.22$ Lat 42014'34", long 70047'22", Cohasset, Mass., Bryant Point, Cohasset Harbor, excellent wet line inside building marked on door of Cohasset Yacht Club at end of Atlantic Avenue. Photo. Tidal surge. 
Table 1.--Flood data in Maine, New Hampshire, and Massachusetts (Continued)

\begin{tabular}{|c|c|c|}
\hline $\begin{array}{l}\text { Site } \\
\text { No. }\end{array}$ & $\begin{array}{c}\text { Elevation } \\
(\mathrm{ft})\end{array}$ & Description \\
\hline 289 & 9.15 & $\begin{array}{l}\text { Lat } 42012^{\prime} 59^{\prime \prime} \text {, long } 70046^{\prime} 17^{\prime \prime} \text {, North Scituate, Mass., Musquash } \\
\text { Brook tributary, excellent debris line, nail, paint, tag on ri } \\
\text { downstream side of culvert on Hollett Street. Photo. Tidal surge. }\end{array}$ \\
\hline 290 & 8.19 & $\begin{array}{l}\text { Lat } 42013^{\prime} \mid 8^{\prime \prime} \text {, long } 70046^{\prime} 42^{\prime \prime} \text {, North Scituate, Mass., Musquash } \\
\text { Brook tributary, good debris line, nail, paint, tag on pole } \\
13 \text { Gannett Road near culvert. Photo. Tidal surge. }\end{array}$ \\
\hline 291 & 10.94 & $\begin{array}{l}\text { Lat } 42014^{\prime} 23 " \text { ", long } 70047 \cdot 30^{\prime \prime} \text { Cohasset, Mass., Cohasset Co } \\
\text { scratch mark found on board attached to side of "Old Ice Hou } \\
\text { adjacent to Hugo's Lighthouse Restaurant, in line with met } \\
\text { Marks of eight storms since } 1851 \text { scratched on this board. } \\
\text { photos. Tidal surge. }\end{array}$ \\
\hline
\end{tabular}

292 Lat 42014'20", long 70045'52", Cohasset, Mass., Minot, North Scituate Beach, Massachusetts Bay, good debris line along bank marked with paint, nail, tag on pole 7 on most northerly east-west street in Minot, at western end of marsh. Photo. Tidal surge.

$293 \quad 11.51 \quad$ Lat 42013'46", long 70045'27", North Scituate, Mass., North Scitude Beach, Massachusetts Bay, excellent debris line, paint and flag on corner post of chain link fence at southern end of tennis court behind seawall on Surfside Road. Two photos. Wave overwash.

294 18.36 Lat 42011'22", long 70043'07", Scituate, Mass., Peggoty Beoch, 15.72 Massachusetts Bay, two fair debris lines on telephone pole with fire alarm box 135, at Second Cliff, marked by nails and green paint, elevations $18.36 \mathrm{ft}$ and $15.72 \mathrm{ft}$. Upper mark believed to be splost affected. Wave bore.

295 16.45 Lat 42010'26", long 70042'56", Scituate, Mass., Rivermoor, Massachusetts Bay, good debris line on road, marked with green paint, opposite house 33 at intersection on shore road in Rivermoor. Wave bore.

$2966.73 \quad$ Lat 42006'02", long 70049'23", U.S. Geological Survey gaging station "Indian Head River at Hanover, Mass.," on right bank at downstrean side of Elm Street bridge, $0.3 \mathrm{mi}$ upstream from Iron Mine Brook, and I mi southwest of Hanover, recorded peak at 1645 February Photo. Tidal surge.

$2979.59 \quad$ Lat 42009'I8", long 70046'35", North Marshfield, Mass., North River, excellent debris line, paint mark on right upstream side of bridge of Bridge Street over North River near Kings Landing. Photo. Tiou surge. 
Table 1.--Flood data in Maine, New Hampshire, and Massachusetts (Continued)

\begin{tabular}{ll}
\hline $\begin{array}{l}\text { Site } \\
\text { No. }\end{array} \begin{array}{l}\text { Elevation } \\
(\mathrm{ft})\end{array}$ & \multicolumn{1}{c}{ Description } \\
\hline $298 \quad 9.91$ & $\begin{array}{l}\text { Lat 42009'38", long 70044'34", Scituate, Mass., North River, } \\
\text { excellent wash line at 6.0 ft mark on staff gage on right downstream } \\
\text { side bridge over North River on State Route 3A, one-half mile south } \\
\text { of Cushing State Park. Photo. Tidal surge. }\end{array}$
\end{tabular}

$299 \quad 11.31$

Lat 42이'28", long 70044'34", Scituate, Mass., Herring River, excellent debris and dust line inside gasoline-dispensing pump transferred to silver paint, nail, tag on pole A9A2 at marina on Herring River just south of James Cemetery Photo. Tidal surge.

$300 \quad 7.35 \quad$ Lat 42005'40", long 70043'06", Marshfield, Mass., South River, good wash line, silver paint on highest point of rock on right bank of South River downstream from bridge and pole 308 off Main Street at junction with Plain Street. Photo. Tidal surge.

301 7.19 Lat 42005'34", long 70042'46", Marshfield, Mass., South River, paint, good debris line, nail, tag on 4 by 4-in post on right downstream side of bridge on street to South River Schools off Plains Street. Photo. Tidal surge.

$302 \quad 7.41 \quad$ Lat $42^{\circ} 05^{\prime} 36^{\prime \prime}$, long 70'42'02", Marshfield, Mass., South River, good debris line, paint, nail, tag on trunk of tree $15 \mathrm{ft}$ northwest of pole I3S on State Route 139 (Ocean Street), 0.5 mi east of junction of Plain, Moraine, and Ocean Streets. Photo. Tidal surge.

Lat 42006'22", long 70०4/'58", Marshfield, Mass., South River, good debris line, paint, nail, tag at base of tree on downstream side of South River Street at south entrance to housing development, $1.2 \mathrm{mi}$ north-northeast of Marshfield. Photo. Tidal surge.

9.2 Lat 42006'49", long 70040'36", Marshfield, Mass., South River, excellent debris line along bank transferred to highest point of isolated rock at end of Field Street on right bank of South River at easterly end of Rexhame. Photo. Survey data not available for review. Tidal surge.

10.18 Lat 42005'30", long 70038'48", Marshfield, Mass., Brant Rock, Massachusetts Bay, excellent heavy debris line on chain link fence marked by green paint near pole X83184 at Bud's Garden Center near Post Office at intersection of Gulf Road, State Route 139 and Ocean Street. Photo. NOTE: Seawall topped by floodwaters. Floodmark probably represents both seawall overwash from east and surge from Green Harbor River to the south. 
Table I.-Flood data in Maine, New Hampshire, and Massachusetts (Continued)

\begin{tabular}{|c|c|c|}
\hline $\begin{array}{c}\text { Site } \\
\text { No. }\end{array}$ & $\begin{array}{c}\text { Elevation } \\
(\mathrm{ft})\end{array}$ & Description \\
\hline 306 & 2.94 & 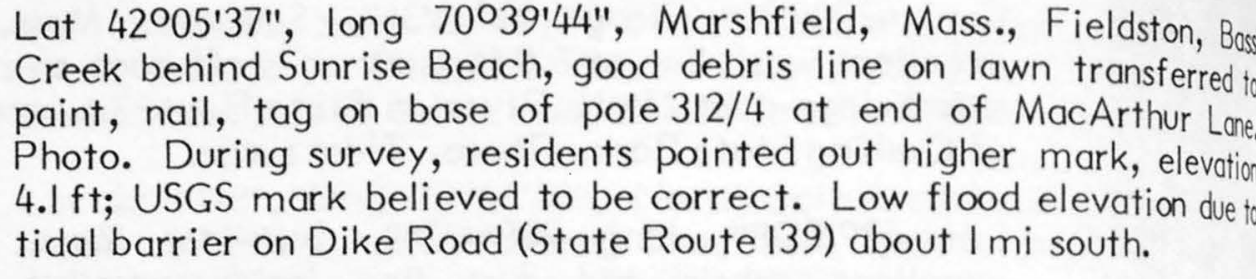 \\
\hline 307 & 9.09 & $\begin{array}{l}\text { Lat } 42^{\circ} 03^{\prime} 58^{\prime \prime} \text { long } 70^{\circ} 40^{\prime} 40^{\prime \prime} \text {, Duxbury, Mass., Little Wood Islan } \\
\text { River, excellent debris line, paint, nail, tag at base of tree seawar } \\
\text { of pole } 462 \text { on State Route } 139 \text {, I mi east of Moraine Street. Photo } \\
\text { Tidal surge. }\end{array}$ \\
\hline
\end{tabular}

$3089.16 \quad$ Lat 42003'24", long 704l'02", Duxbury, Mass., Dug Way River, good debris line, silver paint, nail, tag at base of pole 17 on Duck Hill Road 0.4 mi east of Moraine Street. Photo. Tidal surge.

$309 \quad 10.6$ Lat 42०03'06", long 70040'20", Duxbury, Mass., Dug Way River, Duxbury Marsh, good debris line, paint, nail, tag on third tree seaward from Bay Road $0.2 \mathrm{mi}$ north of intersection with George Street. Two photos. Tidal surge.

$310 \quad 11.48 \quad$ Lat 42002'49", long 70039'05", Duxbury, Mass., Back River behind Duxbury Beach, poor debris line at west end of Powder Point Bridge. Elevation is an approximation, water level approached the top of the bridge. Wave action.

311 9.37 Lat 42002'23", long 70040'35", Duxbury, Mass., Bluefish River, good ice line, silver paint mark on right downstream side of Bluefich River culvert under Harrison Street near intersection of Bay Rood, pole 30 across street. Photo. Tidal surge.

$312 \quad 10.83 \quad$ Lat 42002'53", long 70040'19", Duxbury, Mass., Bluefish River, good debris and wash line, paint, nail, tag on second telephone pole on south side of Powder Point Road east of intersection of Cove Street and Abrams Hill Road. Photo. Floodmark consistent with other floodmark elevations along bank. Probably tidal surge.

$313 \quad 10.16$ Lat 42001'38", long 70\%40'18", Duxbury, Mass., Duxbury Boy, excellent debris line, paint, nail, tag on piling at end of Shipyare Lane about $150 \mathrm{ft}$ south of Ellison Beach Rock monument. Photo. Tidal surge.

$314 \quad 9.87$ Lat 42001'13", long 70041'19", South Duxbury, Mass., The Nook, Kingston Bay, excellent debris line, paint, nail, tag in base of clunp of small trees about $50 \mathrm{ft}$ southwest of pole 704 on Bay Road, $0.3 \mathrm{~m}$ west of Standish Street. Photo. Tidal surge. 
Table 1.--Flood data in Maine, New Hampshire, and Massachusetts (Continued)

Elevation

$(\mathrm{ft})$

Description

10.55 Lat $42^{\circ} 00^{\prime} 44^{\prime \prime}$, long $70^{\circ} 42^{\prime} 02^{\prime \prime}$, South Duxbury, Mass., Kingston Bay, good to fair debris line, paint, nail, tag $2.5 \mathrm{ft}$ above base of last telephone pole on right, at end of Landing Road. Probably some effect from wave bore.

8.7 Lat 40000'32", long 70042'46", South Duxbury, Mass., Miramar, Island Creek, Kingston Bay, excellent debris line, silver paint on left downstream wingwall of Island Creek culvert on Bay Road, about $30 \mathrm{ft}$ southwest of pole 770. Photo. Tidal surge.

10.64 Lat $41^{\circ} 59^{\prime} 27 "$ ", long $70^{\circ} 44^{\prime} 03^{\prime \prime}$, U.S. Geological Survey gaging station "Jones River at Kingston, Mass.," on left bank $100 \mathrm{ft}$ downstream from Elm Street bridge at Kingston and $2.8 \mathrm{mi}$ upstream from mouth. Recorder record faulty, peak from crest-stage gage. Tidal surge.

8.64 Lat 41059'24", long 7043'28", Kingston, Mass., Jones River, good ice line, paint line on right upstream side of State Route $3 \mathrm{~A}$ bridge in Kingston, 2.2 mi upstream from mouth. Photo. Tidal surge.

9.67 Lat 41059'15", long 70042'32", Kingston, Mass., good debris line, paint, nail, tag on tree on north side of State Route $3 \mathrm{~A}$ on left edge of Smelt Brook, $0.5 \mathrm{mi}$ east of junction of State Route 3, $600 \mathrm{ft}$ upstream from railroad bridge. Photo. Tidal surge.

12.18 Lat 4/058'I", long 70040'33", North Plymouth, Mass., Plymouth Harbor, very good debris line, green paint line on chain link fence, tags on post, between two storehouses at end of Robbins Road, storehouse on left has "Bird Building Materials" sign. Photo. Wave bore.

13.18 Lat 41055'22", long 70036'49", Plymouth, Mass., good ice line, paint mark on right downstream side culvert over East Branch of Eel River on Sandwich Road. Photo. Tidal surge.

II.86 Lat 4/055'33", long 70036'5l", Plymouth, Mass., excellent debris line, paint mark on left downstream side culvert over East Branch of Eel River on Cliff ord Road. Photo. Tidal surge.

12.49 Lat 41055'29", long 70036'Il", Plymouth, Mass., good wash line, paint mark on right upstream side retaining wall of culvert over West Branch of Eel River on Sandwich Road. Photo. Tidal surge.

11.85 Lat 41056'31", long 70037'23", Plymouth, Mass., Eel River, excellent debris line, paint mark on left downstream abutment of State Route $3 \mathrm{~A}$ over Eel River, $0.6 \mathrm{mi}$ west of intersection with River Street. Photo. Tidal surge. 
Table 1.--Flood data in Maine, New Hampshire, and Massachusetts (Continued)

\begin{tabular}{lll}
\hline $\begin{array}{l}\text { Site } \\
\text { No. }\end{array}$ & $\begin{array}{c}\text { Elevation } \\
(\mathrm{ft})\end{array}$ & \multicolumn{1}{c}{ Description } \\
\hline 325 & 21.11 & $\begin{array}{l}\text { Lat }\left.4\right|^{\circ} 56^{\prime} 25 ", \text { long } 70^{\circ} 37^{\prime} 09 " \text { " Plymouth, Mass., Warren Cove, good } \\
\text { debris line, nail, paint, tag on telephone pole behind pool of, and to } \\
\text { the right of, Pilgrim Sands Motel on State Route 3A, 0.4 mi west of } \\
\text { intersection of River Street. Photo. Wave bore. }\end{array}$
\end{tabular}

$326 \quad$ 12.23 Lat 4/055'09", long 70033'57", Manomet, Mass., Beaver Dam Brook, excellent wash line, paint mark on left downstream side culvert over Beaver Dam Brook on State Route $3 \mathrm{~A}, 0.4 \mathrm{mi}$ southeast of intersection with White Horse Road. Photo. Tidal surge.

$327 \quad 14.19 \quad$ Lat 41055'46", long 70033'21", Manomet, Mass., White Horse Beach, good debris line, nail, paint, tag on telephone pole 17 on beach side of White Horse Road opposite house 42. Three photos. Wave bore.

$328 \quad 8.74 \quad$ Lat 41050'35", long 70032'27", Ellisville, Mass., Salt Pond, excellent debris line, nail, paint, tag at base of lonely tree on Ellisville Rood at west edge of Salt Pond, $900 \mathrm{ft}$ south of intersection with Stote Route 3A. Photo. Tidal surge.

$329 \quad 17.24 \quad$ Lat 4/047'08", long 70030'36", Sagamore, Mass., Scusset Beach, for wash line, stake in sand behind 335 Phillips Road, $75 \mathrm{ft}$ toward ocean, at telephone pole 55 . Wave bore.

329A 10.1 Lat 4/046.3', long 70030.4', Sandwich, Mass., tide gage at east end of Cape Cod Canal. Record furnished by the U.S. Army Corps of Engineers. Tidal surge.

$330 \quad 17.00 \quad$ Lat $41^{\circ} 46^{\prime} 18^{\prime \prime}$, long 70²9'30", Sandwich, Mass., Town Beach, property owner stated that water reached bottom of rear steps of 17 Freemo Avenue. Wave bore.

331 17.92 Lat 4/046'06", long 70²9'10", Sandwich, Mass., Town Beach, good debris line at top of sand dunes $115 \mathrm{ft}$ seaward from the rear of the house at end of Wood Avenue. Wave bore.

332 17.89 Lat 41045'34", long 70028'00", Sandwich, Mass., Springhill Beach property owner stated that water reached bottom rung of boardwol to ocean at 100 Saltmarsh Road. Wave bore.

3338.93 Lat 4/045'29", long 70027'47", Sandwich, Mass., Old Harbor Creek behind Springhill Beach, debris piled on top of fire hydrant outlet, $23 \mathrm{ft}$ south of telephone pole 8 on Saltmarsh Road. Tidal surge through Sandwich Harbor inlet. 
Table 1.-Flood data in Maine, New Hampshire, and Massachusetts (Continued)

\begin{tabular}{lll}
\hline $\begin{array}{l}\text { Site } \\
\text { No. } \begin{array}{c}\text { Elevation } \\
(\mathrm{ft})\end{array}\end{array}$ & \multicolumn{1}{c}{ Description } \\
\hline 334 & 16.55 & $\begin{array}{l}\text { Lat } 41^{\circ} 44^{\prime} 59 ", \text { long } 70^{\circ} 26^{\prime} 00 " \text { ", Sandwich, Mass., East Sandwich } \\
\text { Beach, fair seed line, stake at rear of 20INorth Shore Boulevard } \\
\text { (Anchor Cottages office). Wave bore. }\end{array}$
\end{tabular}

$335 \quad 14.26$

Lat 4/044'37", long 70024'44", Sandwich, Mass., Scorton Shores, good seed line on bank transferred to nail with flag on 4 by 4 -in post at end of Hammond Road. Wave bore.

3369.78 Lat 4/042'34", long 70019'25", Barnstable, Mass., Barnstable Harbor near Calves Pasture Point, top of flagged stake driven to level of good debris line, at end of Scudder Lane. Accuracy of mark unknown. Tidal surge.

337 10.81 Lat 41042'32", long 70017'53", Barnstable, Mass., Barnstable Harbor, good debris line, keel mark on fourth rise from top of stairs at end of Mill Way. Tidal surge; possibly some effect from wave bore.

$338 \quad 10.00$ Lat 41042'35", long 70015'35", Barnstable, Mass., Short Wharf Creek, good seed line, keel mark $I$ in above bottom of first row of shingles of 121 Wharf Lane. Tidal surge.

339 10.38 Lat 41042'35", long 70015'35", Barnstable, Mass., Short Wharf Creek, good seed line, keel mark on steel post of carport of |2| Wharf Lane. Tidal surge.

$340 \quad 13.18$ Lat $41^{\prime} 4^{\prime} 4^{\prime} 12^{\prime \prime}$, long 70013'40", Dennis, Mass., Cape Cod Bay, wet line in house at same level as top of side door stoop at 37 Dr. Bottera Road. Water broke through dunes just to the west; waves caused flooding.

341 13.35 Lat 41045'05", long 700II'20", Corporation Beach, Mass., Nobscusset Harbor, good debris line verified by marks in vicinity, top of nail with flag in telephone pole 4lA at end of road to Nobscusset Point. Wave bore.

342 13.II Lat 4/046'04", long 7005'II", Brewster, Mass., Cape Cod Bay, keel mark on concrete post in parking area at end of Breakwater Road, at the elevation of debris at edge of parking lot. Accuracy of mark unknown. Wave bore.

$343 \quad 10.0$ Lat $42^{\circ} 02^{\prime} 59^{\prime \prime}$, long 700/1'17", Provincetown, Mass., observed tide levels on surveyor's rod attached to face of concrete seawall at northeast corner of municipal parking lot adjacent to MacMillan Wharf. Observations of 30-second duration at 2-minute intervals. Record furnished by Graham S. Giese, Provincetown Center for Coastal Studies. Tidal surge. 
Table I.--Flood data in Maine, New Hampshire, and Massachusetts (Continued)

\begin{tabular}{|c|c|c|}
\hline $\begin{array}{l}\text { Site } \\
\text { No. }\end{array}$ & $\begin{array}{c}\text { Elevation } \\
(\mathrm{ft})\end{array}$ & Description \\
\hline 344 & 8.31 & $\begin{array}{l}\text { Lat } 41^{\circ} 40^{\prime} 03^{\prime \prime} \text {, long } 70^{\circ} 02^{\prime} 37 " \text { ", South Harwich, Nantucket Sound, } \\
\text { excellent debris line, nail with flag at top of bottom rail of water } \\
\text { barrier at end of Uncle Venies Road. Tidal surge. }\end{array}$ \\
\hline 345 & 6.95 & $\begin{array}{l}\text { Lat } 41^{\circ} 38^{\prime} 07 " \text { ", long } 70^{\circ} 33^{\prime} 26 " \text { ", West Yarmouth, Mass., Sea Gull Beach, } \\
\text { good debris line } 1.00 \mathrm{ft} \text { below nail (elev } 7.95 \mathrm{ft} \text { ) with flag in pile at } \\
\text { shoreline. Tidal surge. }\end{array}$ \\
\hline 346 & $\begin{array}{r}5.94 \\
(\text { nail) } \\
5.96 \\
\text { (keel) }\end{array}$ & $\begin{array}{l}\text { Lat } 41^{\circ} 38^{\prime} 07 " \text { ", long } 70^{\circ} 17^{\prime} 36^{\prime \prime} \text {, Hyannis Port, Mass., Hyannis Harbor, } \\
\text { good debris lines marked by nail with flag on } 2 \text { - by } 6 \text {-in post on foot. } \\
\text { bridge and keel mark on concrete pier of footbridge on Ocean } \\
\text { Avenue. Tidal surge. }\end{array}$ \\
\hline 347 & 4.23 & $\begin{array}{l}\text { Lat 4/04l'30", long } 70^{\circ} 37 \cdot 38^{\prime \prime} \text {, Barlows Landing, Mass., Pocasset } \\
\text { Harbor, good ice line, nail, paint, tag at base of pole } 50 \mathrm{ft} \text { north of } \\
\text { pier at Barlows Landing. Tidal surge. }\end{array}$ \\
\hline 348 & 5.72 & $\begin{array}{l}\text { Lat } 41^{\circ} 45^{\prime} 10^{\prime \prime} \text {, long } 70^{\circ} 42^{\prime} 33^{\prime \prime} \text {, Wareham, Mass., Wareham River, } \\
\text { excellent ice line at } 7.0 \mathrm{ft} \text { mark on staff gage, pointed out by owner } \\
\text { of Warr's Marine dock I, } 600 \mathrm{ft} \text { southeast of powerplant on Maine } \\
\text { Street. Photo. Tidal surge. }\end{array}$ \\
\hline
\end{tabular}


Table 2.--Historical flood data in Maine and Massachusetts

(All flood elevations are in feet above National Geodetic Vertical Datum of 1929. Site numbers are the same as those given in table I and plates I and 2.)

$$
\text { Part A - Maine }
$$

\begin{tabular}{|c|c|c|c|c|c|c|c|}
\hline \multirow[t]{2}{*}{$\begin{array}{l}\text { Site } \\
\text { No. }\end{array}$} & \multicolumn{3}{|c|}{$\begin{array}{l}\text { Date and elevation, } \\
\text { in feet, of flood }\end{array}$} & \multirow[t]{2}{*}{$\begin{array}{l}\text { Site } \\
\text { No. }\end{array}$} & \multicolumn{3}{|c|}{$\begin{array}{l}\text { Date and elevation, } \\
\text { in feet, of flood }\end{array}$} \\
\hline & $* 2-2-76$ & $1-9-78$ & $2-7-78$ & & $* 2-2-76$ & $1-9-78$ & $2-7-78$ \\
\hline 1 & 13.44 & 13.94 & 12.34 & 23 & 12.46 & 9.73 & 9.56 \\
\hline 2 & 12.06 & 11.77 & 10.67 & 24 & 8.93 & 9.73 & 9.03 \\
\hline 3 & 13.96 & 14.06 & 12.66 & 25 & 10.23 & 11.10 & 10.25 \\
\hline 4 & 12.10 & 11.71 & 10.42 & 26 & 8.57 & 10.38 & 9.98 \\
\hline 5 & 12.91 & 12.31 & 11.51 & 27 & 8.41 & 9.59 & 9.02 \\
\hline 6 & 11.59 & 12.40 & 12.00 & 28 & 8.20 & -- & 9.75 \\
\hline 7 & 10.87 & 11.37 & 10.37 & 29 & 8.68 & 10.30 & 9.60 \\
\hline 8 & 10.44 & 10.26 & 10.06 & 30 & 8.45 & 11.20 & 9.50 \\
\hline 9 & 11.39 & 10.27 & 9.97 & 31 & 8.15 & 10.47 & 9.26 \\
\hline 10 & 10.48 & 10.10 & 9.70 & 32 & 7.68 & 10.47 & 9.48 \\
\hline$\|$ & 9.91 & 10.50 & 10.10 & 33 & 7.09 & -- & 9.29 \\
\hline 12 & 9.57 & 10.30 & 9.91 & 34 & 7.27 & -- & 9.18 \\
\hline 13 & 8.23 & - & 9.54 & 42 & - & 8.09 & 8.00 \\
\hline 14 & 10.90 & 11.03 & 11.53 & 52 & -- & 9.42 & 9.00 \\
\hline 15 & 9.42 & 10.92 & 11.42 & 53 & -- & 9.76 & 9.06 \\
\hline 16 & 9.51 & 10.48 & 9.12 & 54 & -- & 9.52 & 9.30 \\
\hline 17 & 9.52 & 12.07 & 9.54 & 56 & - & 9.56 & 10.35 \\
\hline 18 & 7.85 & 9.91 & 9.24 & 57 & -- & 10.94 & 9.38 \\
\hline 19 & 9.16 & 9.68 & 8.24 & 59 & - & 9.35 & 9.02 \\
\hline 20 & 11.56 & 11.31 & 10.16 & 60 & - & 9.36 & 9.03 \\
\hline 21 & 16.66 & 11.66 & 11.16 & 62 & - & 9.48 & 8.57 \\
\hline 22 & 12.68 & 11.12 & 10.62 & 65 & - & 10.03 & 9.26 \\
\hline
\end{tabular}

tota previously published in Morrill (1977) with different site numbers. 
Table 2.--Historical flood data in Maine and Massachusetts (Continued)

$$
\text { Part B - Massachusetts }
$$

Site number 291. A board attached to "Old Ice House" at Hugo's Lighthouse Restaurant, in Cohasset, has been marked with several flood events since 1851. It is not known what floods, if any, were not marked.

\begin{tabular}{lccccc}
\hline *Year & $\begin{array}{c}\text { Observed } \\
\text { elevation } \\
(\mathrm{ft})\end{array}$ & $\begin{array}{c}\text { **Adjusted } \\
\text { elevation } \\
(\mathrm{ft})\end{array}$ & *Year & $\begin{array}{c}\text { Observed } \\
\text { elevation } \\
(\mathrm{ft})\end{array}$ & $\begin{array}{c}\text { **Adjusted } \\
\text { elevation } \\
(\mathrm{ft})\end{array}$ \\
\hline 1978 & 10.94 & 10.94 & 1938 & 9.08 & 9.48 \\
1954 & 9.70 & 10.00 & 1851 & 8.81 & 9.81 \\
1898 & 9.61 & 10.51 & 1931 & 8.38 & 8.88 \\
1956 & 9.44 & 9.64 & 1945 & 8.03 & 8.43 \\
\hline
\end{tabular}

* Month and day not recorded.

** Observed values after adjustment for rising sea level; adjustment made to 1980 sea. level conditions, based on Hicks (1978).

Part C - Site number 74A. Maximum stillwater tide heights at Portland, Maine tide gage

(Records have been collected by National Ocean Survey since March 1910. Records were furnished by U.S. Army Corps of Engineers.)

\begin{tabular}{|c|c|c|c|c|c|}
\hline Date & $\begin{array}{l}\text { Observed } \\
\text { elevation } \\
(\mathrm{ft})\end{array}$ & $\begin{array}{c}\text { Adjusted } \\
\text { elevation } \\
(\mathrm{ft})\end{array}$ & Date & $\begin{array}{l}\text { Observed } \\
\text { elevation } \\
(\mathrm{ft})\end{array}$ & $\begin{array}{c}\text { Adjusted } \\
\text { elevation } \\
(\mathrm{ft})\end{array}$ \\
\hline $\begin{array}{r}2-7-78 \\
11-30-44 \\
11-20-45 \\
4-7-58 \\
12-29-59\end{array}$ & $\begin{array}{l}9.6 \\
8.7 \\
8.7 \\
8.5 \\
8.5\end{array}$ & $\begin{array}{l}9.6 \\
8.9 \\
8.9 \\
8.6 \\
8.6\end{array}$ & $\begin{array}{r}12-23-68 \\
4-14-72 \\
12-9-50 \\
12-11-50 \\
4-13-53\end{array}$ & $\begin{array}{l}7.9 \\
7.9 \\
7.8 \\
7.8 \\
7.8\end{array}$ & $\begin{array}{l}8.0 \\
7.9 \\
8.0 \\
8.0 \\
8.0\end{array}$ \\
\hline $\begin{array}{r}2-19-72 \\
3-4-3 \mid \\
4-2 \mid-40 \\
|-20-6| \\
\mid 1-2-63\end{array}$ & $\begin{array}{l}8.5 \\
8.4 \\
8.2 \\
8.2 \\
8.1\end{array}$ & $\begin{array}{l}8.5 \\
8.8 \\
8.5 \\
8.3 \\
8.2\end{array}$ & $\begin{array}{r}10-25-53 \\
12-11-69 \\
3-18-72 \\
12-\quad 2-74 \\
2-5-47\end{array}$ & $\begin{array}{l}7.8 \\
7.8 \\
7.8 \\
7.8 \\
7.7\end{array}$ & $\begin{array}{l}8.0 \\
7.9 \\
7.8 \\
7.8 \\
7.9\end{array}$ \\
\hline $\begin{array}{r}11-20-72 \\
4-4-73 \\
11-19-18 \\
12-7-19 \\
8-31-54\end{array}$ & $\begin{array}{l}8.1 \\
8.1 \\
8.0 \\
8.0 \\
7.9\end{array}$ & $\begin{array}{l}8.1 \\
8.1 \\
8.5 \\
8.5 \\
8.1\end{array}$ & $\begin{array}{l}2-8-47 \\
3-3-47 \\
3-\mid 7-56 \\
5-26-67 \\
3-|7-7|\end{array}$ & $\begin{array}{l}7.7 \\
7.7 \\
7.7 \\
7.7 \\
7.7\end{array}$ & $\begin{array}{l}7.9 \\
7.9 \\
7.9 \\
7.8 \\
7.7\end{array}$ \\
\hline $\begin{array}{r}|2-2|-60 \\
4-\quad-6 \mid\end{array}$ & $\begin{array}{l}7.9 \\
7.9\end{array}$ & $\begin{array}{l}8.0 \\
8.0\end{array}$ & $\begin{array}{l}|1-3-7| \\
12-22-72\end{array}$ & $\begin{array}{l}7.7 \\
7.7\end{array}$ & $\begin{array}{l}7.7 \\
7.7\end{array}$ \\
\hline
\end{tabular}

* Observed values after adjustment for rising sea level; adjustment made to $1975 \mathrm{sec}$ level conditions, based on Hicks (1978). 
Table 2.--Historical flood data in Maine and Massachusetts (Continued)

Part D - Site number 256B. Maximum stillwater tide heights at Boston, Massachusetts

(Records have been collected since 1723. Elevations from 1723 to 1850 are of questionable reliability. Yearly records collected by several

Federal agencies from 1851 to 1921 are believed to be accurate.

Continuous record collected by National Ocean Survey since May 1921.

Records were furnished by the U.S. Army Corps of Engineers.)

\begin{tabular}{|c|c|c|c|c|c|}
\hline Date & $\begin{array}{l}\text { Observed } \\
\text { elevation } \\
(\mathrm{ft})\end{array}$ & $\begin{array}{l}\text { *Adjusted } \\
\text { el evation } \\
(\mathrm{ft})\end{array}$ & Date & $\begin{array}{l}\text { Observed } \\
\text { elevation } \\
(\mathrm{ft})\end{array}$ & $\begin{array}{l}\text { *Adjus ted } \\
\text { elevat ion } \\
(\mathrm{ft})\end{array}$ \\
\hline $\begin{array}{l}2.7-78 \\
4.14-1851 \\
1.26-09 \\
1.27-1898 \\
12.29-59\end{array}$ & $\begin{array}{r}10.4 \\
10.1 \\
10.0 \\
9.4 \\
9.3\end{array}$ & $\begin{array}{r}10.4 \\
11.0 \\
10.6 \\
10.1 \\
9.4\end{array}$ & $\begin{array}{r}11-30-44 \\
1-20-61 \\
3-17-56 \\
4-7-58 \\
3-7-62\end{array}$ & $\begin{array}{l}8.8 \\
8.8 \\
8.6 \\
8.5 \\
8.4\end{array}$ & $\begin{array}{l}9.1 \\
8.9 \\
8.7 \\
8.6 \\
8.5\end{array}$ \\
\hline $\begin{array}{l}4.18-1852 \\
1.15-1839 \\
1.27-1839 \\
2.24-1723 \\
2.19-72\end{array}$ & $\begin{array}{l}9.2 \\
9.2 \\
9.2 \\
9.1 \\
9.1\end{array}$ & $\begin{array}{r}10.1 \\
10.2 \\
10.2 \\
10.7 \\
9.1\end{array}$ & $\begin{array}{r}12-2-74 \\
1-28-33 \\
4-\quad 4-73 \\
12-22-72 \\
11-12-47\end{array}$ & $\begin{array}{l}8.4 \\
8.3 \\
8.3 \\
8.3 \\
8.2\end{array}$ & $\begin{array}{l}8.4 \\
8.7 \\
8.3 \\
8.3 \\
8.4\end{array}$ \\
\hline $\begin{array}{l}3.26-1830 \\
1.4-1786 \\
4-21.40 \\
5.26-67 \\
3.4-31\end{array}$ & $\begin{array}{l}9.0 \\
8.9 \\
8.9 \\
8.9 \\
8.8\end{array}$ & $\begin{array}{r}10.0 \\
10.2 \\
9.2 \\
8.9 \\
9.2\end{array}$ & $\begin{array}{r}2-28-52 \\
8-31-54 \\
11-2-63 \\
2-7-74 \\
4-13-53\end{array}$ & $\begin{array}{l}8.2 \\
8.2 \\
8.2 \\
8.2 \\
8.1\end{array}$ & $\begin{array}{l}8.4 \\
8.4 \\
8.3 \\
8.2 \\
8.3\end{array}$ \\
\hline
\end{tabular}

Woberved values after adjustment for rising sea level; adjustment made to 1970 sealevel conditions, based on Hicks (1978). 